\title{
The use of soluble African horse sickness viral protein 7 as an antigen delivery and presentation system
}

\author{
Daria A. Rutkowska ${ }^{\mathrm{a}}$, Quinton C. Meyer ${ }^{\mathrm{a}}$, Francois Maree ${ }^{\mathrm{b}}$, Volos ${ }^{1}$, Wilma Fick ${ }^{\mathrm{a}}$ and \\ Henk Huismans $^{\mathrm{a}}$ \\ ${ }^{a}$ Department of Genetics, University of Pretoria, Pretoria 0002, South Africa \\ ${ }^{b}$ Transboundary Animal Diseases Program, Onderstepoort Veterinary Institute, Agricultural Research Council, \\ Onderstepoort, Pretoria 0110, South Africa \\ Corresponding author. \\ ${ }^{1}$ Current address: Australian Animal Health Laboratory, Private Bag 24, Geelong 3220, Australia.
}

\begin{abstract}
We have investigated the use of soluble chimeric trimers of the major capsid protein VP7 of African horse sickness virus (AHSV) as a vaccine delivery system by targeting some of the natural hydrophilic loops on the VP7 top domain for the insertion of foreign peptides. Key to this trimer display strategy is the solubility of AHSV VP7 and how the solubility of this hydrophobic protein can be manipulated by inserting peptides into the top domain. To investigate, we generated different cloning vectors by inserting multiple cloning sites at three different positions in the VP7 gene. These modifications inserted six amino acids at the cloning sites and in some cases this converted VP7 to a largely soluble protein without affecting the ability of the modified proteins to form trimers. The vectors were used to generate a number of soluble VP7 fusion proteins including a fusion with a 36 amino acid insert that overlaps important immunological domains on protein VP1 of foot and mouth disease virus (FMDV) as well as a 110 amino acid peptide derived from AHSV VP2. Soluble trimers of these fusion proteins were able to elicit a good insert-specific immune response in guinea pigs. 1-Arginine was found to reverse protein aggregation and was employed as an effective strategy to isolate relatively pure soluble chimeric VP7 trimers. Another factor that increased VP7 solubility in both wild-type VP7 and one of the VP7 vector proteins was the substitution of the leucine residue in position 345 of the VP7 Cterminus with a hydrophilic arginine residue.
\end{abstract}

Keywords: African horse sickness virus; Foot and mouth disease virus; Immune display; Soluble VP7 trimers; Fusion proteins

\section{Introduction}

The optimised display of immunologically important and protective epitopes to the immune system is a key factor in the development of recombinant vaccines. One strategy is to display such epitopes on the surface of viral and other multimeric particles (Pumpens et al., 1995). Such a particle display method has been explored for bluetongue virus (BTV), the prototype member of the orbivirus genus ([Burroughs et al., 1994] and [Roy, 1996a]). The double-stranded RNA genome of BTV encodes seven structural and three nonstructural proteins. Of these, nonstructural protein NS1 has been used for the display of foreign epitopes on tubular particles 
([Ghosh et al., 2002] and [Larke et al., 2005]) and major proteins VP7 and VP3 for presentation of epitopes on the surface of core-like particles (CLPs) ([Adler et al., 1998] and [Tanaka et al., 1995]). The use of these proteins is based on the observation that, when they are co-expressed in insect cells, they spontaneously assemble into CLPs that resemble the normal icosahedral BTV core particles ([Le Blois and Roy, 1993] and [Limn et al., 2000]). Foreign peptides may be inserted into these proteins and presented to the immune system on the surface of chimeric CLPs. However, this strategy is restricted to only those chimeric proteins that are able to assemble into stable CLPs (Tanaka et al., 1995). None of the proteins of any of the other orbiviruses, such as African horse sickness virus (AHSV), have been investigated with respect to their potential for presenting foreign antigens to the immune system. A number of important differences between the equivalent AHSV and BTV proteins, however, present some unique challenges and opportunities with respect to their use in peptide display.

AHSV VP7 is a very hydrophobic and largely insoluble protein (Basak et al., 1996). When the protein is expressed in virus-infected cells or by means of baculovirus expression the protein forms hexagonal, disc-shaped crystals of approximately $6 \mu \mathrm{m}$ in diameter ([Burroughs et al., 1994] and [Chuma et al., 1992]). These particles have been utilized in a subunit vaccine strategy to protect against a virulent viral challenge (Wade-Evans et al., 1997). This suggested the use of chimeric VP7 particles for the display of foreign peptides instead of a chimeric CLP strategy which is not viable due to the low yield of CLPs when AHSV VP7 and VP3 proteins are coexpressed in insect cells (Maree et al., 1998). Although the structural elements and amino acids that play a role in BTV VP7 solubility, trimerization and CLP formation have been analyzed in great detail (Limn et al., 2000), little is known about the factors that underlie AHSV VP7 insolubility and particle formation. It has, however, been shown that the largely insoluble protein is composed of trimers that are stable in the presence of SDS at room temperature (Monastyrskaya et al., 1997).

Due to the insolubility of AHSV VP7, it has not been possible to determine the structure of both the bottom and top domains of this protein with only the latter structure determined at an atomic level (Basak et al., 1996). It was found to be very similar to that of the top domain of BTV VP7, which is composed of amino acids 121-249 folded into an anti-parallel $\beta$-sandwich (Grimes et al., 1995). The bottom domain of BTV VP7 consists of the first 120 amino acids at the Nterminus and the last 99 residues at the C-terminus of the protein. The two domains are twisted anti-clockwise in the VP7 trimer so that the top domain of one monomer is positioned above the bottom domain of the adjacent monomer, primarily over the $\mathrm{C}$-terminal region (Grimes et al., 1995).

Our initial interest in the use of chimeric AHSV VP7 proteins as a vaccine delivery system stemmed from the possibility of using chimeric VP7 particles for immune display. This option was expanded to include the use of soluble chimeric VP7 trimers for immune display following the observation that in a number of cases, the insertion of small peptides into the AHSV VP7 top domain increased the solubility of the chimeric VP7 proteins without affecting their ability to form trimers. These inserts ranged from small 6 amino acid peptides to larger peptides such as a 36 amino acid peptide containing a cluster of highly conserved linear B-cell epitopes on VP1 of foot-and-mouth disease virus (FMDV) (Aggarwal and Barnett, 2002) and a 110 amino acid peptide that overlaps several important antigenic domains on VP2, the major neutralization- 
specific antigen of AHSV (Martinez-Torrecuadrada et al., 2001). We could demonstrate that such soluble chimeric VP7 trimers were able to induce a strong insert-specific humoral immune response and in the case of the FMDV insert, high titres of neutralizing antibodies in guinea pigs.

\section{Materials and methods}

\subsection{Maintenance and generation of recombinant baculoviruses}

Recombinant baculoviruses, were generated by the Bac-to-Bac ${ }^{\circledR}$ baculovirus expression system (Invitrogen) (Luckow et al., 1993) and propagated in Spodoptera frugiperda (Sf9) cells. Cells were maintained in suspension or monolayer cultures at $27^{\circ} \mathrm{C}$ using TC100 medium supplemented with $10 \%(\mathrm{v} / \mathrm{v})$ foetal calf serum (FCS), an antibiotic-antimycotic solution (Highveld Biological) and 0.08\% Pluronic F-68 (Sigma). To generate recombinant baculoviruses, bacmid DNA was transfected into Sf9 cells using Cellfectin reagent. Cells were incubated at $27^{\circ} \mathrm{C}$ until evidence of baculovirus infection was obtained (4 days), after which virus-containing supernatants were collected and stored at $4{ }^{\circ} \mathrm{C}$ until further use. Pure recombinant viral stocks were prepared from single plaques using established procedures. A recombinant plaque-purified baculovirus, capable of expressing wild-type (WT) AHSV-9 VP7 in Sf9 cells (Maree et al., 1998) was available at the start of the investigation. A baculovirus recombinant that expressed the BTV-10 VP7 gene was also available.

\subsection{Modified AHSV-9 VP7 vector constructs}

The sites for the insertion of foreign peptides were selected from a hydrophilicity plot of the top domain of AHSV VP7 which indicated three small hydrophilic sites in the region of amino acids 144, 177 and 200 respectively. The location of the sites is indicated in a view of the VP7 top domain in Fig. 1. The regions downstream of these three amino acid sites were targeted for the insertion of foreign peptides by the insertion of an 18 nucleotide DNA fragment specifying restriction enzyme (RE) sites HindIII, XbaI and SalI downstream of the codons encoding amino acids 144, 177 and 200 of the AHSV-9 VP7 gene. This resulted in the insertion of amino acids KLSRVD $\left(\mathrm{P}_{1}\right)$ generating VP7 vector proteins VP7-144( $\left.\mathrm{P}_{1}\right), \mathrm{VP7}-177\left(\mathrm{P}_{1}\right)$ and VP7-200( $\left.\mathrm{P}_{1}\right)$, respectively. To complement the range of cloning sites, we also generated vector protein VP7144 $\left(\mathrm{P}_{2}\right)$ in which peptide PGEFLE $\left(\mathrm{P}_{2}\right)$ was inserted downstream of VP7 amino acid position 144. This peptide is encoded by a DNA fragment containing RE sites SmaI, EcoRI and XhoI.

All constructs were designed for expression by baculovirus recombinants as described in the Bac-to-Bac manual (Invitrogen). In all the cloning protocols the high fidelity TaKaRa Ex Taq ${ }^{\mathrm{TM}}$ PCR kit (TAKARA BIO INC.) was used for PCR amplifications. The $50 \mu \mathrm{l}$ PCR reactions were set up according to the manufacture's instruction using a final concentration of $0.5 \mu \mathrm{M}$ for each primer and the following cycling conditions: 1 cycle of $94{ }^{\circ} \mathrm{C}$ for $3 \mathrm{~min}$ followed by 30 cycles of $94{ }^{\circ} \mathrm{C}$ for $20 \mathrm{~s}, 55^{\circ} \mathrm{C}$ for $30 \mathrm{~s}$ and $72{ }^{\circ} \mathrm{C}$ for $45 \mathrm{~s}$ followed by 1 cycle of $72{ }^{\circ} \mathrm{C}$ for $15 \mathrm{~min}$. The oligonucleotide primer sequences used in all the cloning strategies are provided in Table 1 with the restriction enzyme sites highlighted in bold. All amplicons and constructs were verified by chain termination sequencing (Applied Biosystems). 

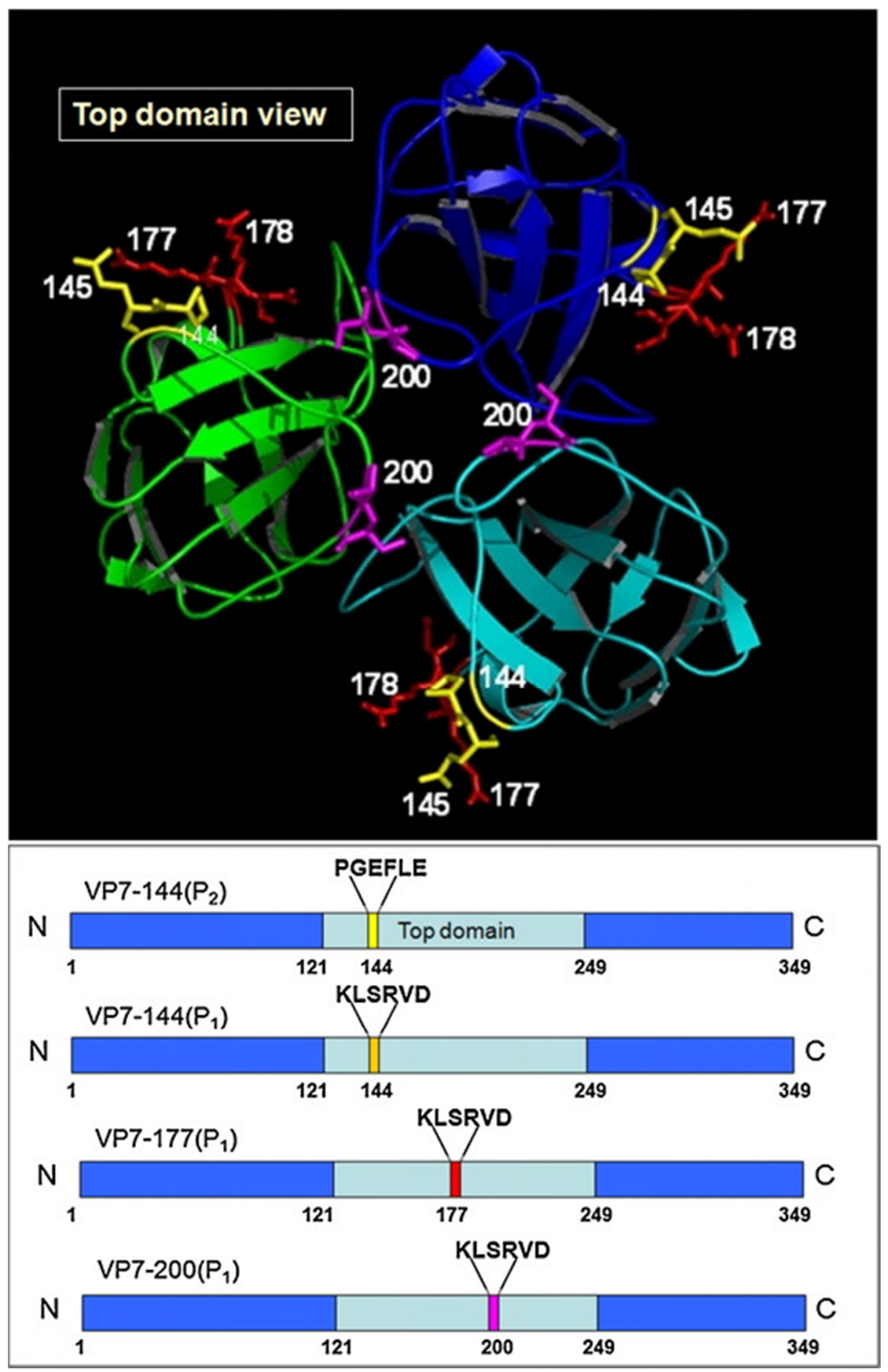

Fig. 1. A schematic representation of the crystallographic structure of the top domain of AHSV VP7 trimer, looking vertically into the top of the trimer. The VP7 monomers are coloured in blue, cyan and green. The hydrophilic, surface exposed regions of the trimer targeted in this study for mutagenesis are shown in red at position 177-178, in yellow at 144-145 and magenta at position 200-201. A schematic representation of the 4 different AHSV VP7 vector proteins is shown in the bottom panel with the 6-mer $P_{1}$ and $P_{2}$ peptide inserts downstream of amino acids 144, 177 and 200. (For interpretation of the references to colour in this figure legend, the reader is referred to the web version of the article.) 
Table 1. Primers used in construction of VP7 vectors, VP7 fusion proteins and VP7L345R mutants.

\begin{tabular}{|c|c|c|c|}
\hline VP7 vectors & Primer $^{\mathrm{a}}$ & $5^{\prime}-3^{\prime}$ sequence $^{b}$ & RE sites \\
\hline \multirow[t]{2}{*}{ VP7-144( $\left(\mathrm{P}_{1}\right)$} & $\mathrm{O} 1 \mathrm{~F}$ & GGCTCTAGAGTCGACCAAGGTCGAACGCGTGG & $\begin{array}{l}\text { XbaI-- } \\
\text { SalI }\end{array}$ \\
\hline & $\mathrm{O} 2 \mathrm{R}$ & GGCTCTAGAAAGCTTCGGTACGTAATATCTGCC & $\begin{array}{l}\text { XbaI- } \\
\text { HindIII }\end{array}$ \\
\hline \multirow[t]{2}{*}{ VP7-177( $\left.\mathrm{P}_{1}\right)$} & $\mathrm{O} 3 \mathrm{~F}$ & GCTCTAGAGTCGACAGGGGGGACGCAGTCATG & $\begin{array}{l}\text { XbaI-- } \\
\text { SalI }\end{array}$ \\
\hline & O4R & GCTCTAGAAAGCTTCCTTGGGGCTAGCAGCGC & $\begin{array}{l}\text { XbaI- } \\
\text { HindIII }\end{array}$ \\
\hline \multirow[t]{2}{*}{ VP7-200( $\left.\mathrm{P}_{1}\right)$} & $\mathrm{O} \mathrm{O5F}$ & GCTCTAGAGTCGACTCACTTGAGAGCGCTCC & $\begin{array}{l}\text { XbaI- } \\
\text { SalI }\end{array}$ \\
\hline & O6R & GCTCTAGAAAGCTTCGCACCTTGAGGATCAC & $\begin{array}{l}\text { XbaI- } \\
\text { HindIIII }\end{array}$ \\
\hline \multirow[t]{2}{*}{ VP7-144( $\left.\mathrm{P}_{2}\right)$} & $\mathrm{O} 7 \mathrm{~F}$ & GGCGAATTCCTCGAGCAAGGTCGAACGCGTGG & $\begin{array}{l}\text { EcoRI- } \\
\text { XhoI }\end{array}$ \\
\hline & O8R & GGCGAATTCCCCGGGCGGTACGTAATATCTTGCC & $\begin{array}{l}\text { EcoRI- } \\
\text { SmaI }\end{array}$ \\
\hline \multirow[t]{2}{*}{ VP7 external } & $\mathrm{O} 9 \mathrm{~F}$ & CACAGATCTTTCGGTTAGGATGGACGCG & $B g l \mathrm{II}$ \\
\hline & O10R & CACAGATCTGTAAGTGTATTCGGTATTGAC & $B g l$ III \\
\hline $\begin{array}{l}\text { VP7 fusion } \\
\text { proteins }\end{array}$ & Primer $^{\mathbf{a}}$ & $5^{\prime}-3^{\prime}$ sequence ${ }^{b}$ & RE sites \\
\hline \multirow[t]{2}{*}{$\begin{array}{l}\left.\text { VP7-177( } \mathrm{P}_{1}\right)- \\
\text { FMDVepi }\end{array}$} & $\mathrm{O} 11 \mathrm{~F}$ & CGGAAGCTTAGATACAACGGTGAGTGC & HindIII \\
\hline & O12R & CGGGTCGACGGTAGACGGGAGTTTGTG & SalI \\
\hline \multirow{2}{*}{$\begin{array}{l}\left.\text { VP7-144( } \mathrm{P}_{2}\right)- \\
\text { FMDVepi }\end{array}$} & $\mathrm{O} 13 \mathrm{~F}$ & CGGGAATTCAGATACAACGGTGAGTGC & EcoRI \\
\hline & O14R & CGGCTCGAGGGTAGACGGGAGTTTGTG & XhoI \\
\hline \multirow{2}{*}{$\begin{array}{l}\text { VP7-144( }\left(\mathrm{P}_{2}\right)- \\
\text { VP2(110aa) }\end{array}$} & $\mathrm{O} 15 \mathrm{~F}$ & GGCGAATTCGATAAGCAGGGG & EcoRI \\
\hline & O16R & GGCCTCGAGTGGTTGTCCTCC & XhoI \\
\hline \multirow[t]{2}{*}{$\begin{array}{l}\left.\text { VP7-177( } \mathrm{P}_{1}\right)- \\
\text { VP2epiB }\end{array}$} & $\mathrm{O} 19 \mathrm{~F}$ & GGGAAGCTTGTAGATGTTGATCCGAATAAG & HindIII \\
\hline & O20R & GGGGTCGACCGCTTTCTTCAATTTTTCGG & SalI \\
\hline $\begin{array}{l}\text { VP7 L345R } \\
\text { mutants }\end{array}$ & Primer $^{\mathbf{a}}$ & $5^{\prime}-3^{\prime}$ sequence ${ }^{\underline{b}}$ & RE sites \\
\hline \multirow[t]{2}{*}{$\begin{array}{l}\text { VP7-L345R, } \\
\left.\text { VP7-177( } \mathrm{P}_{1}\right)- \\
\text { L351R }\end{array}$} & $\mathrm{O} 21 \mathrm{~F}$ & CAGCCCGGGCAGCCTACCACTAGTGGC & SmaI \\
\hline & $\mathrm{O} 22 \mathrm{R}$ & CAGCCCGGGCAAGAGCTCTGTTGATCT & SmaI \\
\hline
\end{tabular}

${ }^{\mathrm{a}}$ Primer orientation forward $(\mathrm{F})$, reverse $(\mathrm{R})$.

${ }^{\mathrm{b}} \mathrm{RE}$ sites highlighted in bold. 
Plasmid vector, pFastBac1-VP7, constructed to generate a recombinant baculovirus expressing the VP7 gene of AHSV-9 (Maree et al., 1998), was used as template in the cloning strategy to generate the three vector proteins. The strategy involved amplifying the VP7 vector genes as two fragments from the pFastBac1-VP7 DNA template using the primers outlined in Table 1. For example, in the construction of VP7-144( $\left.\mathrm{P}_{1}\right)$, internal oligonucleotide primer O1F was used in combination with VP7 external primer O10R to amplify the $3^{\prime}$ end fragment. Primers O2R and O9F were similarly used to amplify the 5'-end fragment. The resulting VP7 amplicons of the 5' and $3^{\prime}$ end gene fragments were first cloned into the pMosBlue -T vector (GE Healthcare) and then re-cloned into the $B a m H \mathrm{I} / X b a \mathrm{I}$ and $X b a \mathrm{I} / K p n \mathrm{I}$ RE sites of plasmid pFastBac1 (Invitrogen) respectively, after removal of the additional HindIII site present in the pFastbac 1 multiple cloning site. The other VP7 vector genes were constructed using the same strategy. A fourth cloning vector, VP7-144( $\left(\mathrm{P}_{2}\right)$ was generated by inserting a DNA fragment that specifies RE sites SmaI, EcoRI and XhoI in the VP7 gene, resulting in the insertion of peptide PGEFLE $\left(\mathrm{P}_{2}\right)$ downstream of amino acid 144 in the VP7 top domain.

To introduce a site specific leucine to arginine substitution mutation at positions 345 and 351 in WT-VP7 and VP7-177( $\left.\mathrm{P}_{1}\right)$ respectively, an inverse PCR strategy was employed using oligonucleotide primers O21F and O22R. Plasmids pFastBac1-VP7 and pFastBac1-VP7$177\left(\mathrm{P}_{1}\right)$ were used as templates. The strategy was designed to create a SmaI site at the target nucleotide position which resulted in the required codon change after SmaI digestion and self ligation of the PCR amplicon. PCR cycling conditions were as follows: 1 cycle of $94^{\circ} \mathrm{C}$ for 5 min followed by 30 cycles of $94{ }^{\circ} \mathrm{C}$ for $1 \mathrm{~min}, 58^{\circ} \mathrm{C}$ for $30 \mathrm{~s}, 72{ }^{\circ} \mathrm{C}$ for 6 min and 1 cycle of $72{ }^{\circ} \mathrm{C}$ for $15 \mathrm{~min}$.

\subsection{Construction of VP7-177( $\left.P_{1}\right)$ and VP7-144( $\left(P_{2}\right)$ fusion proteins}

For the construction of VP7-FMDVepi fusion protein a sequence, encoding a cluster of B-cell epitopes (amino acids 129-164) located on the 1D gene of FMDV, was amplified using a plasmid containing a part of the genome of FMDV vaccine strain SAT2/ZIM/7/83 as template (van Rensburg et al., 2002). VP7-177( $\left.\mathrm{P}_{1}\right)$-FMDVepi and VP7-144( $\left.\mathrm{P}_{2}\right)$-FMDVepi were constructed after cloning the resulting PCR amplicons into either vector VP7-177( $\left.\mathrm{P}_{1}\right)$ or VP7$144\left(\mathrm{P}_{2}\right)$ utilizing the HindIII and SalI or EcoRI and XhoI sites, respectively.

For the construction of the VP7-VP2 fusion proteins a Topo plasmid containing the AHSV4VP2 gene was used as template to amplify gene fragments encoding epiB (aa 377-400) (Martinez-Torrecuadrada et al., 2001) and a larger 110aa fragment that overlaps epiB (aa 298408). These fragments were cloned using the HindIII and SalI sites of VP7-177( $\left.\mathrm{P}_{1}\right)$ to generate VP7-177(P1)-VP2epiB. The EcoRI and XhoI sites of VP7-144( $\left.\mathrm{P}_{2}\right)$ were used to generate VP7144( $\left.\mathrm{P}_{2}\right)$-VP2(110aa). PCR conditions were as described by the manufacturers (TAKARA BIO INC.). PCR cycling conditions were as follows: 1 cycle of $94{ }^{\circ} \mathrm{C}$ for $3 \mathrm{~min}, 30$ cycles of $94{ }^{\circ} \mathrm{C}$ for $20 \mathrm{~s}, 50{ }^{\circ} \mathrm{C}$ for $30 \mathrm{~s}, 72^{\circ} \mathrm{C}$ for $30 \mathrm{~s}$ followed by 1 cycle of $72{ }^{\circ} \mathrm{C}$ for $15 \mathrm{~min}$. 


\subsection{Fractionation and characterization of soluble and particulate VP7 proteins}

VP7 vector and fusion proteins were expressed in recombinant baculovirus-infected Sf9 cells and harvested 48 or $72 \mathrm{~h}$ post-infection. Cell monolayers, harvested from $75 \mathrm{~cm}^{2}$ flasks (Nunc), were resuspended in $800 \mu$ lysis buffer $\left(0.01 \mathrm{M}\right.$ STE with $0.5 \%$ Nonidet ${ }^{\circledR-} \mathrm{P} 40$ (Roche)) incubated on ice for $30 \mathrm{~min}$ and homogenized. The soluble VP7 proteins were separated from aggregated or particulate VP7 by high speed centrifugation or by fractionation on sucrose gradients. In case of the latter a cellular lysate was layered onto a $5 \mathrm{ml} \mathrm{50-70 \% (w/v)} \mathrm{sucrose} \mathrm{gradient} \mathrm{in} 0.01 \mathrm{M} \mathrm{STE}$ (10 mM Tris, $50 \mathrm{mM}$ EDTA, $10 \mathrm{mM} \mathrm{NaCl}, \mathrm{pH}$ 7.4) and centrifuged in a Beckman SW55Ti rotor at $30000 \mathrm{rpm}$ for $18 \mathrm{~h}$ at $4{ }^{\circ} \mathrm{C}$. Fractions of $500 \mu \mathrm{l}$ each were collected from the bottom of the tube and the pellet resuspended in $500 \mu \mathrm{l}$ of $0.01 \mathrm{M} \mathrm{STE}$. The protein content of the fractions and pellet were analyzed by $12 \%$ SDS-polyacrylamide gel electrophoresis (SDS-PAGE). Equal samples of the pellet and gradient fractions were denatured at $95{ }^{\circ} \mathrm{C}$ in the presence of $4 \% \mathrm{SDS}$ prior to electrophoresis. Gels were stained with Coomassie Brilliant Blue staining solution (0.125\% Coomassie Blue, 50\% methanol, 10\% acetic acid) and destained in 5\% methanol; 5\% acetic acid. For immunoblot analysis the proteins on a PAGE gel were transferred to a Hybond nitrocellulose membrane (Amersham) by standard procedures. Membranes were incubated in buffer with a guinea pig anti-VP7 primary antibody. Peroxidase-conjugated Protein A (ICN) was used as the secondary antibody.

In order to detect the presences of VP7 multimers or trimers, PAGE analysis of the proteins was carried out without heat denaturation of the protein samples in loading buffer prior to electrophoresis (Monastyrskaya et al., 1997). This method detects trimers or multimers that are stable in the presence of SDS at room temperature. VP7 trimerization was also confirmed by sedimentation analysis as described for BTV VP7 trimers (Limn et al., 2000). Cellular lysates containing either soluble AHSV or BTV VP7 proteins were centrifuged on 10-50\% sucrose gradients for $18 \mathrm{~h}$ at $50000 \mathrm{rpm}$ in a Beckman SW55Ti rotor at $4{ }^{\circ} \mathrm{C}$ in the presence of sedimentation size markers catalase $(250 \mathrm{kDa})$, l-lactate dehydrogenase $(140 \mathrm{kDa})$ and bovine serum albumin $(66 \mathrm{kDa})$.

\subsection{Quantification of the relative amount of protein in the soluble fraction}

The relative amount of soluble VP7 protein in the gradients was calculated from both the Coomassie Blue stained PAGE gels and/or the corresponding immunoblot membranes by scanning the VP7 bands in the pellet and gradient fractions using the EZQuant software package (EZQuant Ltd.). The sum of the scanned values in the soluble fractions of the gradient, normally fractions 7-9 in a 10 fraction gradient, was then expressed as a percentage of the total VP7 calculated from the sum of the scanned VP7 values in the pellet and all the gradient fractions.

\subsection{Scanning electron microscopy (SEM) of particulate VP7}

Fractions containing particulate VP7 protein were diluted five-fold with $1 \times$ phosphate buffered saline buffer (137 mM NaCl, $\left.2.7 \mathrm{mM} \mathrm{KCl,} 4.3 \mathrm{mM} \mathrm{Na}_{2} \mathrm{HPO}_{4} \cdot 2 \mathrm{H}_{2} \mathrm{O}, 1.4 \mathrm{mM} \mathrm{KH} \mathrm{PO}_{4}, \mathrm{pH} 7.3\right)$ and recovered via centrifugation at $5000 \mathrm{rpm}$ for $45 \mathrm{~min}$ for scanning electron microscopy analysis. Samples of the purified particulate VP7 protein were fixed in $0.15 \mathrm{M} \mathrm{Na}_{2} \mathrm{HPO}_{4}, 0.1 \%$ glutaraldehyde at room temperature for $30 \mathrm{~min}$. The fixed particulate protein samples were 
filtered onto a $0.22 \mu \mathrm{m}$ nylon filter (Schleicher \& Shuell), washed three times in $0.075 \mathrm{M}$ $\mathrm{Na}_{2} \mathrm{HPO}_{4}$ and dehydrated by successive treatment in $50 \%, 70 \%, 90 \%$ and $100 \%$ ethanol. The treatment with $100 \%$ ethanol was repeated three times after which the filters were dried in a critical point drier with liquid $\mathrm{CO}_{2}$, mounted onto an aluminium stub and splatter coated with gold-palladium in a SEM auto-coating unit E5200 (Polaron Equipment Ltd.). The stub was viewed at $5.0 \mathrm{kV}$ in a Jeol 840 scanning electron microscope.

\subsection{Antigen preparation for guinea pig trials}

The soluble and particulate VP7-177( $\left.\mathrm{P}_{1}\right)$-FMDVepi proteins used in the first guinea pig trial were prepared by separation of the soluble and particulate fractions by sucrose gradient sedimentation analysis as described above. Fractions containing the soluble and particulate proteins were pooled, dialyzed against sterile $0.01 \mathrm{M} \mathrm{STE}$ buffer at $4{ }^{\circ} \mathrm{C}$, freeze dried and resuspended in PBS buffer prior to use.

Arginine or sarkosyl solubilized VP7-177( $\left.\mathrm{P}_{1}\right)$-FMDVepi, VP7-177( $\left.\mathrm{P}_{1}\right)$-VP2epiB and VP7144( $\left.\mathrm{P}_{2}\right)$-VP2(110aa) proteins were prepared as follows: Sf9 cells infected with the appropriate recombinant baculovirus were harvested $72 \mathrm{~h}$ after infection. Cellular lysates were prepared and the particulate protein fraction collected by centrifugation through a $40 \%$ sucrose cushion at $15000 \mathrm{rpm}$ for $20 \mathrm{~min}$ in a Beckman SW28 rotor at $4{ }^{\circ} \mathrm{C}$. The proteins were resuspended in PBS, treated with either $1 \mathrm{M}$ l-arginine (Merck) or $0.5 \% \mathrm{Na}^{+} \mathrm{N}$-Lauroylsarcosine (Sarkosyl) (Merck), incubated at $25^{\circ} \mathrm{C}$ for $30 \mathrm{~min}$ and centrifuged to remove residual insoluble proteins. The soluble arginine-treated samples were not subjected to any further purification protocols. The sarkosylsolubilized VP7-177( $\left.\mathrm{P}_{1}\right)$-FMDVepi was dialyzed against sterile distilled water to remove excess sarkosyl detergent. The arginine- and sarkosyl-solubilized protein samples were freeze-dried in a Freezone 2.5 freeze-drier (Labconco) for $72 \mathrm{~h}$ and reconstituted in sterile water. The proteins were recovered with no detectable loss of soluble protein. The quantity of VP7 protein was calculated from a standard curve drawn using known quantities of bovine serum albumin (BSA).

\subsection{Measuring immune response in guinea pig trials}

The guinea pig trials were conducted under the strict supervision of the Onderstepoort Animal Ethics Committee according to national standards. The studies were performed at the Transboundary Animal Diseases Program (TADP) of the Onderstepoort Veterinary Institute (OVI). Separate vaccines were formulated by combining the VP7 antigen solutions with an equal volume with one of the following adjuvants: Freunds, incomplete Freunds, an AlOH/Saponin combination or as double oil emulsions with Montanide ISA 206B. Female guinea pigs (500$600 \mathrm{~g}$ ), acquired from Onderstepoort Biological Products were immunized subcutaneously with between $20 \mu \mathrm{g}$ and $80 \mu \mathrm{g}$ of the VP7 antigen, as indicated in results, in a final volume of $500 \mu \mathrm{l}$ which included $250 \mu \mathrm{l}$ of the adjuvant. Boost inoculations, with the same antigen dose and adjuvant mixtures were administered three weeks after the primary inoculation. Guinea pigs were bled prior to immunization, before the boost inoculation at 21 days and three weeks after the boost inoculation (day 42 of the animal trial). 


\subsection{Analysis of FMDV antibodies by ELISA and virus neutralization}

Sera from the experimental animals were tested for the presence of anti-FMDV antibodies via indirect ELISA. SAT2/ZIM/7/83 was added to 96 well microtitre plates previously coated with rabbit anti-ZIM/7/83 antiserum. The guinea pig sera were mixed with equal volumes of negative bovine serum prior to dilution onto the plates. Horseradish peroxidase-conjugated rabbit antiguinea pig IgG (Sigma-Aldrich), diluted 1:100 in casein, was added for $1 \mathrm{~h}$ at $37^{\circ} \mathrm{C}$ and the plates washed with PBS-Tween-80. The substrate solution, 3,3',5,5' tetramethylbenzidine (TMB) sodium phosphate/citric acid buffer and $\mathrm{H}_{2} \mathrm{O}_{2}$ was added and incubated for $15 \mathrm{~min}$ at room temperature. The reactions were stopped with $1 \mathrm{M} \mathrm{H}_{2} \mathrm{SO}_{4}$ and the optical density (OD) at $492 \mathrm{~nm}$ was measured with a Labsystems Multiscan Plus Photometer. Titration endpoints are expressed as the $\log _{10}$ reciprocal of the highest dilution at which the signal obtained is twice the signal of the negative control. Under these conditions pre-bleed sera and negative controls had ELISA titres of 1.3 or less.

The presence of neutralizing FMDV antibodies in the sera of VP7-177( $\left.\mathrm{P}_{1}\right)$-FMDVepi inoculated animals was detected via cross-neutralization assays in micro-titre plates on IB-RS-2 cells as described in the OIE Manual of Standards (2009). The neutralization assays used SAT2/ZIM $7 / 83$ to determine the presence and titres of the FMDV neutralizing antibodies. The titres were expressed as the $\log _{10}$ reciprocal of the last dilution of serum to neutralize 100 TCID50 in 50\% of the wells (Rweyemamu et al., 1978). All the data were statistically analyzed by a two sample $t$-test assuming unequal variance.

\subsection{Analysis of AHSV antibodies by ELISA and virus neutralization}

Sera from guinea pigs inoculated with VP7 fusion proteins with peptide inserts from AHSV-4 VP2, such as VP7-177( $\left.\mathrm{P}_{1}\right)$-VP2epiB and VP7-144( $\left.\mathrm{P}_{2}\right)$-VP2(110aa), were tested for the presence of VP2epiB-specific antibodies via indirect ELISA assays. The ELISA plates were coated with AHSV-4 VP2epiB-BSA, a conjugate of AHSV-4 VP2 epitope B peptide (VDVDPNKGKWKEHIKEVTEKLKKA) and BSA in a 5:1 ratio (GL Biochem (Shanghai) Ltd.). The titration endpoints were calculated as the dilution at which the signal obtained is above the signal of the negative control. Plaque-reducing neutralization assays were performed with AHSV-4 on Vero cells to determine the titres of the AHSV-4 neutralizing antibodies in the sera of the VP7-177( $\left.\mathrm{P}_{1}\right)-\mathrm{VP} 2 \mathrm{epiB}$ or VP7-144( $\left.\mathrm{P}_{2}\right)-\mathrm{VP} 2(110 \mathrm{aa})$-inoculated animals. The virus neutralizing antibody titres were expressed as the $\log _{10}$ reciprocal of the serum dilution causing a $50 \%$ reduction in the number of plaques. All the data were statistically analyzed as described above.

\section{Results}

\subsection{Construction and characterization of VP7 presentation vectors}

The crystallographic structure of the top domain of AHSV VP7 has indicated the presence of three distinct hydrophilic, surface exposed $\beta$-loops at amino acids 144-145, 200-201 and 175180, with the latter forming a flexible loop containing an RGD motif (Basak et al., 1996). These

sites were confirmed by hydrophilicity plots of the AHSV VP7 top domain and were targeted for 
the downstream insertion of foreign peptides. Multiple cloning sites in the VP7 gene top domain were generated via the insertion of an 18 nucleotide DNA fragment, specifying RE sites for HindIII, $X b a \mathrm{I}$ and SalI and encoding amino acids KLSRVD $\left(\mathrm{P}_{1}\right)$ downstream of the codons encoding amino acids 144, 177 and 200, respectively. These modified AHSV VP7 genes were used to generate VP7 vector proteins VP7-144( $\left.\mathrm{P}_{1}\right)$, VP7-177( $\left.\mathrm{P}_{1}\right)$ and VP7-200( $\left.\mathrm{P}_{1}\right)$. To complement the range of cloning sites, we also generated vector protein VP7-144( $\left(\mathrm{P}_{2}\right)$ in which peptide PGEFLE $\left(\mathrm{P}_{2}\right)$, encoded by a DNA fragment containing RE sites SmaI, EcoRI and XhoI, was inserted downstream of VP7 amino acid position 144. The location of the insertion sites in the VP7 top domain and a diagrammatic representation of the four different vector proteins is shown in Fig. 1.

The vector proteins, as well as an unmodified wild-type (WT) VP7 control (Maree et al., 1998), were expressed by baculovirus recombinants in Sf9 insect cells. SDS-PAGE analysis of the expressed proteins indicated in each case the presence of a unique $39 \mathrm{kDa}$ protein that reacted positively with VP7-specific antibodies in an immunoblot (results not shown). To determine the effect of these insertion mutations on VP7 solubility and particle formation, cellular lysates containing vector proteins VP7-144( $\left.\mathrm{P}_{1}\right), \mathrm{VP} 7-177\left(\mathrm{P}_{1}\right), \mathrm{VP7}-200\left(\mathrm{P}_{1}\right), \mathrm{VP} 7-144\left(\mathrm{P}_{2}\right)$ and WT VP7 prepared from cells harvested at $72 \mathrm{~h}$ after infection, were subjected to sucrose gradient sedimentation analysis. Sucrose gradient fractions were analyzed by SDS-PAGE and immunoblotting with VP7 specific antibodies as shown in Fig. 2. Fractions 7-9, indicated by double sided arrows, contained the soluble VP7 and cellular proteins. The VP7 identity of the $39 \mathrm{kDa}$ bands in the stained gels was confirmed by immune blots. The relative amount of soluble VP7 protein was determined as described from both the immune blots and stained gels. The results confirmed that AHSV WT VP7 is a largely insoluble protein with less than $10 \%$ of the expressed protein located in the soluble fractions. In contrast, the insertion of $\mathrm{P}_{2}$ downstream of amino acid 144 in the VP7 top domain converted VP7-144( $\left.\mathrm{P}_{2}\right)$ to a largely soluble protein with as much as $60 \%$ of the expressed protein located in soluble fractions. When $\mathrm{P}_{1}$ was inserted into the same site, less than $10 \%$ of the VP7-144( $\left(\mathrm{P}_{1}\right)$ protein was in the soluble fraction, with the majority of the protein distributed amongst the rest of the gradient and pellet fraction. The insertion of $\mathrm{P}_{1}$ downstream of amino acid 177 also resulted in a significant increase in VP7 solubility with about $30 \%$ of the expressed protein in the soluble fractions. The insertion of $\mathrm{P}_{1}$ downstream of amino acid 200 had no discernable effect on solubility. These solubility profiles were found to be reproducible in three or more independent repeats of the same experiment.

SDS-PAGE has been used to demonstrate that AHSV VP7 forms a trimer that can be distinguished from the $39 \mathrm{kDa}$ monomer provided the samples are not heated above room temperature prior to electrophoresis (Monastyrskaya et al., 1997). To determine the effect of the protein modifications on VP7 trimer formation, the sucrose gradient fractions of WT-VP7, VP7177( $\left.\mathrm{P}_{1}\right)$, VP7-144( $\left.\mathrm{P}_{1}\right)$, VP7-144( $\left.\mathrm{P}_{2}\right)$ and VP7-200( $\left.\mathrm{P}_{1}\right)$ shown in Fig. 2, were analyzed by SDSPAGE and immune blotting under conditions as described in the legend to Fig. 3A. The results with AHSV WT VP7 showed no indication of the $39 \mathrm{kDa}$ monomer but revealed a shift of the VP7 specific protein to a high molecular weight protein band migrating just above the $172 \mathrm{kDa}$ marker. An identical shift of the monomer to a multimer was observed with VP7-177( $\left.\mathrm{P}_{1}\right)$. However, in the case of VP7-200( $\left.\mathrm{P}_{1}\right)$ only the $39 \mathrm{kDa}$ monomer was observed, suggesting that 


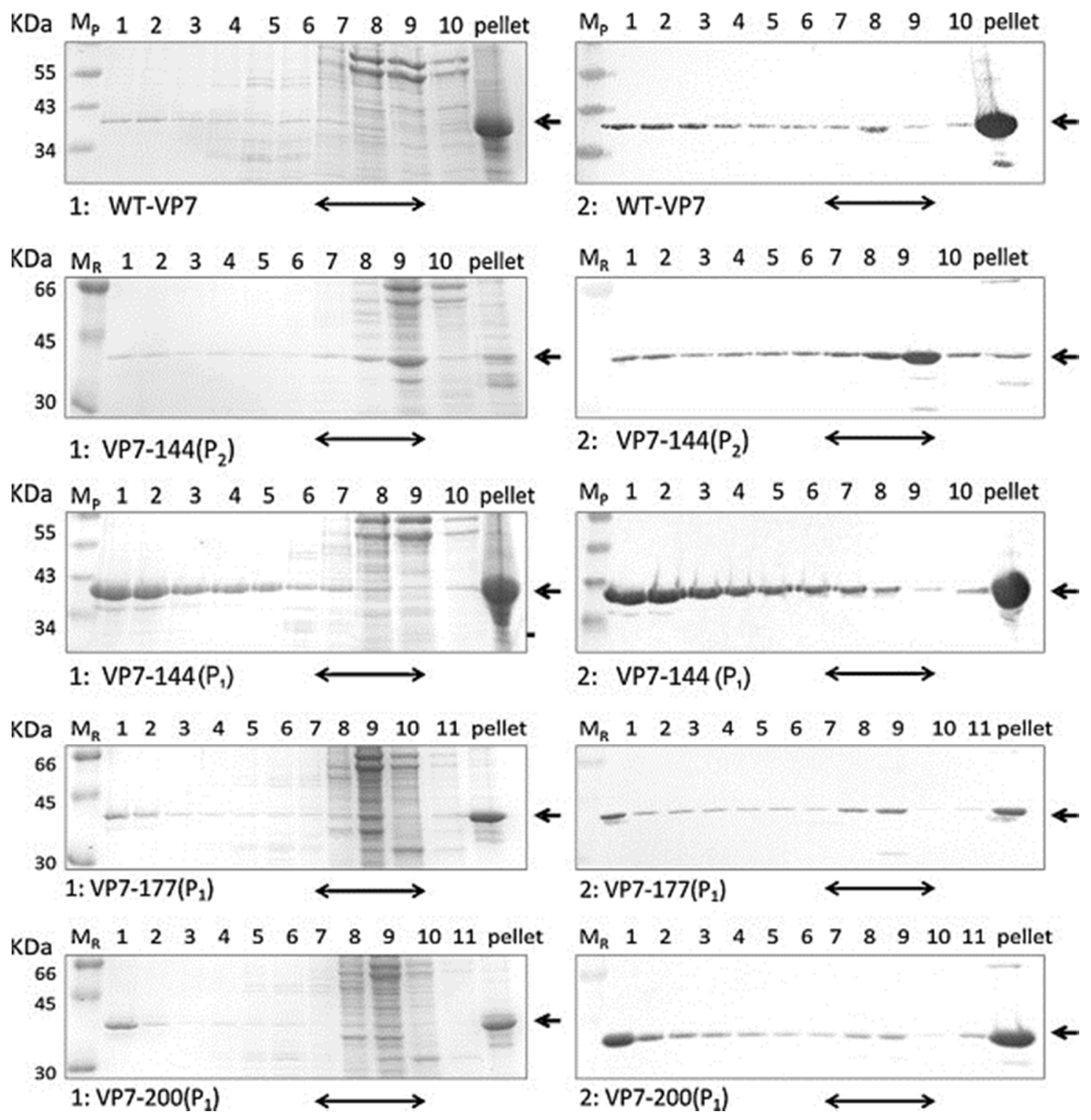

Fig. 2. SDS-PAGE and immunoblots of the sucrose gradient fractions following sedimentation analysis cellular lysates containing proteins WT VP7, VP7-144( $\left(\mathrm{P}_{2}\right), \mathrm{VP}-144\left(\mathrm{P}_{1}\right)$, VP7-177( $\left.\mathrm{P}_{1}\right)$ and VP7-200( $\left.\mathrm{P}_{1}\right)$. Cellular lysates were layered onto 50-70\% sucrose gradients and centrifuged in a Beckman SW 55Ti rotor for $18 \mathrm{~h}$ at $30000 \mathrm{rpm}$. Fractions were collected from the bottom of the tube and equal quantities of each fraction and the pellet analyzed by SDS-PAGE and Coomassie Blue staining (1) as well as immunoblotting using guinea pig anti-VP7 antibodies (2). The double sided arrow at the bottom of the gel $/ \mathrm{membrane}$ indicates the soluble fractions of the gradient. The arrow on the side indicates, in each case, the position of VP7 protein on the gel $/$ membrane. $M_{\mathrm{R}}$ and $M_{\mathrm{P}}$ are Rainbow ${ }^{\mathrm{TM}}$ and PageRuler ${ }^{\mathrm{TM}}$ prestained molecular size protein ladders respectively. 


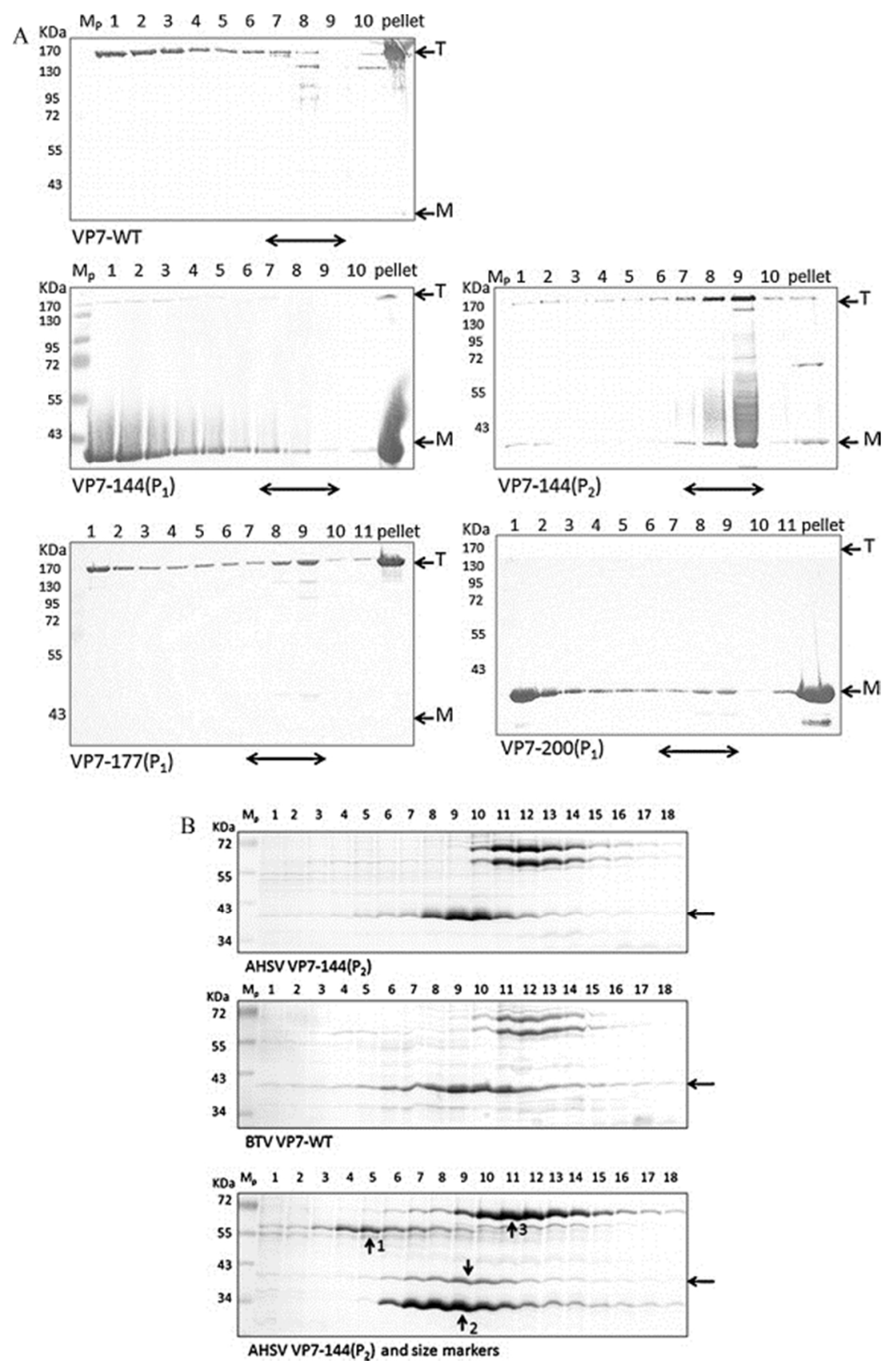

Fig. 3. (A) Immunoblot analyses to assess the stability of different AHSV VP7 trimers in the presence of SDS at room temperature. Sucrose gradient fractions of AHSV WT-VP7, VP7-144( $\left(\mathrm{P}_{1}\right), \mathrm{VP7}-144\left(\mathrm{P}_{2}\right), \mathrm{VP7}-177\left(\mathrm{P}_{1}\right)$ and VP7-200 $\left(\mathrm{P}_{1}\right)$ proteins were analyzed as in Fig. 2 except that the protein samples were incubated at room temperature rather than at $95{ }^{\circ} \mathrm{C}$ prior to SDS-PAGE. The VP7 proteins in the immune blot were identified with guinea pig antiVP7 antibodies. The large VP7 multimer and presumed trimer position is indicated by a $\mathrm{T}$ and the monomer protein by an M. $M_{\mathrm{P}}$ is a PageRuler ${ }^{\mathrm{TM}}$ prestained molecular size protein ladder respectively. (B) Sucrose sedimentation analysis of the soluble fractions of AHSV VP7-144( $\left.\mathrm{P}_{2}\right)$ and BTV VP7. Sf9 cells lysates containing expressed BTV VP7 or AHSV VP7-144( $\left.\mathrm{P}_{2}\right)$ proteins were centrifuged at $50000 \mathrm{rpm}$ in an SW55 rotor for $18 \mathrm{~h}$ at $4{ }^{\circ} \mathrm{C}$ on $10-50 \%$ sucrose gradients. The gradients were fractionated into 28 fractions and each fraction analyzed by SDS-PAGE and Coomassie Blue staining as shown in the first two panels. The size of the VP7-144( $\left.\mathrm{P}_{2}\right)$ multimer was assessed by cosedimentation of three marker proteins in the same gradient. These were: (1) catalase $(250 \mathrm{kDa})$ consisting of four $60-65 \mathrm{kDa}$ subunits; (2) l-lactate dehydrogenase (140 kDa) consisting of four $36.5 \mathrm{kDa}$ subunits and (3) bovine serum albumin $(66 \mathrm{kDa})$. 
the multimer was unstable in the presence of SDS at room temperature. The results with VP7144 $\left(\mathrm{P}_{1}\right)$ and VP7-144 $\left(\mathrm{P}_{2}\right)$ indicated that, in both cases, a certain portion of these proteins migrated as a monomer with the remainder migrating as the high molecular weight multimer. We made the assumption that this multimer was a trimer based on the previous studies carried out with AHSV WT VP7 and the observation that the size of the WT-VP7 multimer corresponded exactly to that of VP7-177( $\left.\mathrm{P}_{1}\right)$, VP7-144( $\left(\mathrm{P}_{2}\right)$ and VP7-144 $\left(\mathrm{P}_{1}\right)$ when analyzed under a variety of electrophoretic conditions on the same gel. However, the size of the multimer was much larger than the predicted size of the $120 \mathrm{kDa}$ VP7 trimer. Since the large multimer was also observed in the soluble fractions of VP7-144( $\left.\mathrm{P}_{2}\right)$ it raised the question of how the sedimentation profile of soluble VP7-144( $\left.\mathrm{P}_{2}\right)$ would compare to that of soluble BTV WT VP7 (Limn et al., 2000). Such a comparison is shown in Fig. 3B and indicated that the soluble fractions of VP7-144( $\left.\mathrm{P}_{2}\right)$ and BTV VP7 have the same sedimentation profile. Also shown is the VP7-144( $\left.\mathrm{P}_{2}\right)$ sedimentation profile in the presence of 250, 140 and $66 \mathrm{kDa}$ size markers. This indicated a size of the VP7-144( $\left.\mathrm{P}_{2}\right)$ multimer to just less than $140 \mathrm{kDa}$ which would correspond to the predicted size of a VP7 trimer. Subsequent experiments, conducted under the same conditions as the experiment in Fig. 3B indicated that the soluble fractions of AHSV WT VP7, VP7-144( $\left.\mathrm{P}_{1}\right), \mathrm{VP7}-144\left(\mathrm{P}_{2}\right), \mathrm{VP} 7-177\left(\mathrm{P}_{1}\right)$ and VP7-200( $\left.\mathrm{P}_{1}\right)$, all sedimented in a position expected of a $120 \mathrm{kDa}$ VP7 trimer (result not shown).

\subsection{Characterization of VP7 with a FMDV peptide inserted into its top domain}

To address the question of how the different vector proteins are affected by the insertion of foreign peptides, we explored two insertion vectors as candidates for immune display. Vector VP7-144 $\left(\mathrm{P}_{2}\right)$ was selected because it is the most soluble of the VP7 modified proteins and vector VP7-177 $\left(\mathrm{P}_{1}\right)$ because of its trimer stability and a large soluble fraction of approximately $30 \%$. The FMDV VP1 peptide (aa 129-164), containing the immunodominant $\beta \mathrm{G}-\beta \mathrm{H}$ loop was inserted into sites $144\left(\mathrm{P}_{2}\right)$ and $177\left(\mathrm{P}_{1}\right)$ in the VP7 top domain. Sucrose gradient sedimentation analysis following the expression of the fusion proteins VP7-177( $\left.\mathrm{P}_{1}\right)$-FMDVepi and VP7144( $\left(\mathrm{P}_{2}\right)$-FMDVepi proteins in baculovirus-infected insect cells is shown in Fig. 4. The identity of these proteins was confirmed by an immunoblot with AHSV VP7 antiserum (result not shown). VP7-177( $\left.\mathrm{P}_{1}\right)$-FMDVepi was found to have a soluble fraction of more than $40 \%$, an increase over the solubility of the original VP7-177( $\left.\mathrm{P}_{1}\right)$ vector. In contrast, the solubility of the VP7-144( $\left.\mathrm{P}_{2}\right)$ was reduced to less than $15 \%$ following the insertion of FMDV peptide into the $144\left(\mathrm{P}_{2}\right)$ site. The bulk of the VP7-144( $\left.\mathrm{P}_{2}\right)$-FMDVepi protein was in the pellet fraction of the gradient. The VP7177 $\left(\mathrm{P}_{1}\right)$-FMDVepi gradient was also analyzed as described in Fig. 3A. No monomers were found in any of the gradient fractions and VP7-177( $\left.\mathrm{P}_{1}\right)$-FMDVepi migrated as a large multimeric protein of uniform size that was distinctly larger than the multimeric protein observed in the case of VP7-177( $\left.\mathrm{P}_{1}\right)$ (result not shown). The soluble protein fraction was also analyzed by sucrose sedimentation analysis as in Fig. 3B and confirmed that VP7-177( $\left.\mathrm{P}_{1}\right)$-FMDVepi forms a stable trimer in solution (result not shown). 

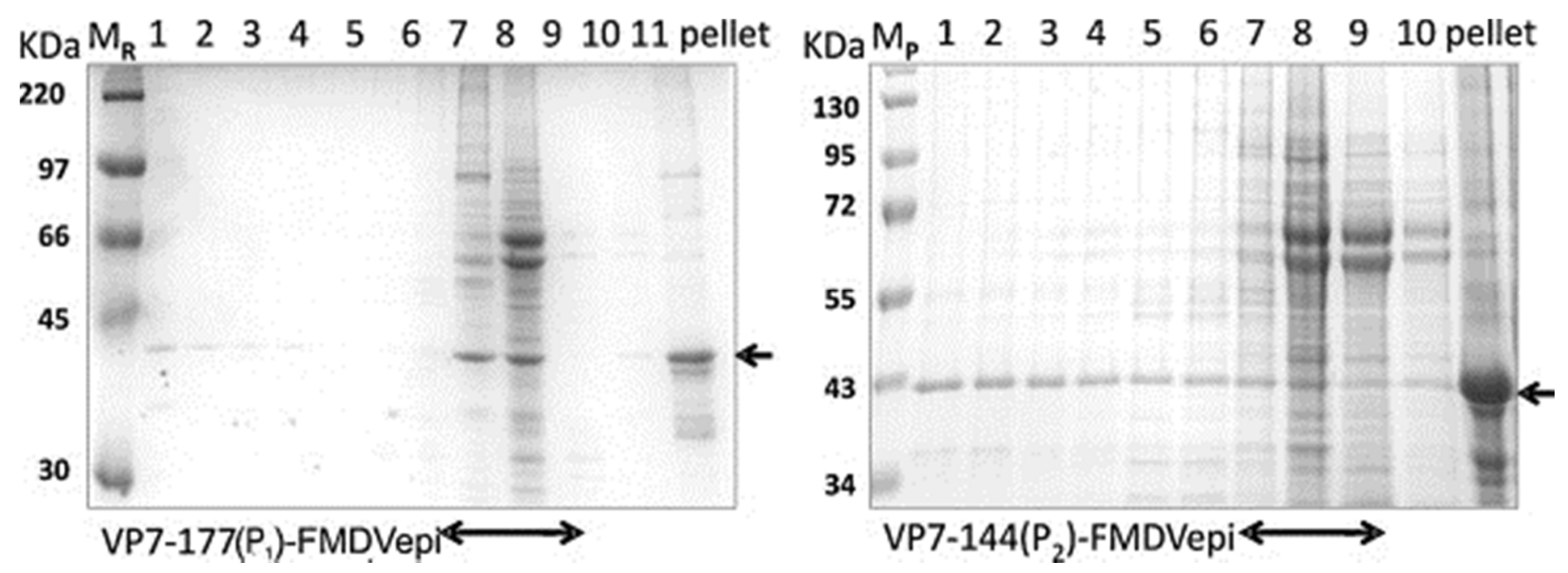

Fig. 4. SDS-PAGE analyses of the fractions obtained following sucrose gradient sedimentation of VP7 fusion proteins VP7-177( $\left.\mathrm{P}_{1}\right)$-FMDVepi and VP7-144( $\left.\mathrm{P}_{2}\right)$-FMDVepi as described in the legend of Fig. 2. Sucrose gradient fractions and pellets were analyzed via SDS-PAGE and the proteins visualised by Coomassie Blue staining. The double sided arrow at the bottom of the gel indicates the soluble fractions of the gradient. $M_{\mathrm{R}}$ and $M_{\mathrm{P}}$ are Rainbow ${ }^{\mathrm{TM}}$ and PageRuler ${ }^{\mathrm{TM}}$ prestained molecular size protein ladders, respectively. The arrow on the side of gel indicates the position of a unique protein, corresponding to the expected size of the VP7-FMDV fusion protein.

SEM analysis of the particulate fractions of WT VP7, VP7-177( $\left.\mathrm{P}_{1}\right)$ and VP7-177( $\left.\mathrm{P}_{1}\right)$-FMDVepi showed that the WT-VP7 and VP7-177 $\left(\mathrm{P}_{1}\right)$ particles were largely indistinguishable and were in the form of the characteristic stacked, flat, hexagonal structures, 6-7 $\mu \mathrm{m}$ in diameter (Fig. 5A and B). The insertion of amino acids KLSRVD downstream of amino acid position 177 in WT VP7 top domain did not interfere with the ability of this protein to assemble into hexagonal, crystal-like particles. However, the VP7-177( $\left.\mathrm{P}_{1}\right)$-FMDVepi particles (Fig. 5C) are clearly distinguishable from those of WT VP7 and VP7-177 $\left(\mathrm{P}_{1}\right)$. Although the particles are approximately the same size, they appeared to be uneven and distorted, lacking the flat surface structure of the other VP7 proteins.

The presence of both a soluble and a particulate VP7-177( $\left.\mathrm{P}_{1}\right)$-FMDVepi protein fraction, raised the question which of these would induce the best insert-specific immune response. Previous studies had shown only a very weak insert-specific immune response against a range of chimeric VP7 particles (unpublished results). To investigate, we carried out a small pilot study in guinea pigs to compare the response against the soluble trimer fraction of VP7-177( $\left.\mathrm{P}_{1}\right)$-FMDVepi with that elicited against the particulate fraction. The result (not shown) indicated a strong FMDV specific ELISA and virus neutralization response against the soluble fraction of VP7-177( $\left.\mathrm{P}_{1}\right)$ FMDVepi with a relatively weak response against the particulate fraction. These preliminary results were supported by further guinea pig trials with the result of one of these summarized in Table 2. Guinea pigs were inoculated with $40 \mu$ g soluble or particulate VP7-177( $\left.\mathrm{P}_{1}\right)$-FMDVepi. An antigen with no insert (VP7-177( $\left.\left.\mathrm{P}_{1}\right)\right)$ was included as a negative control. There was a measurable antibody response against the soluble fraction at 21 days after inoculation. This 

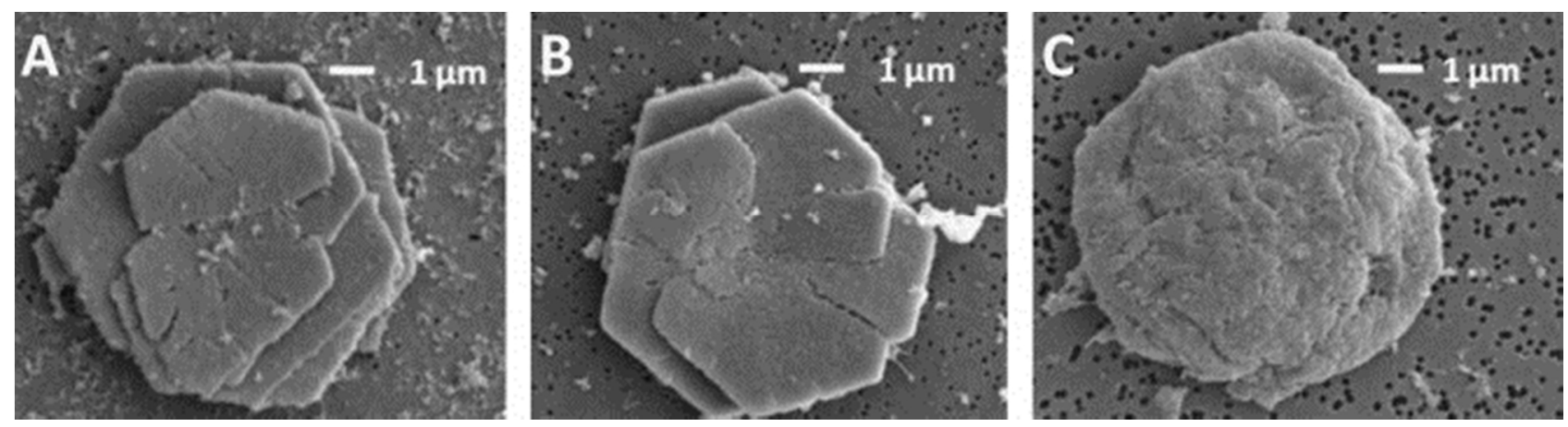

Fig. 5. Scanning electron microscopy (SEM) images of the particles characteristically observed in the particulate fractions of (A) WT VP7, (B) VP7-177( $\left.\mathrm{P}_{1}\right)$ or $(\mathrm{C})$ VP7-177( $\left.\mathrm{P}_{1}\right)$-FMDVepi proteins. The white bar in A, B and C equals $1 \mu \mathrm{m}$.

response was significantly enhanced by the boost and at day 42 the average $\log _{10}$ reciprocal ELISA and neutralization titres were in the order of 3.7 and 2.6 respectively as compared to titres of 2.2 and 1.5 elicited against the particulate fraction. These differences are significant with $t$-test data analysis of the ELISA and virus neutralization titres indicating $p$-values of 0.0105 and 0.004 respectively. Since these results indicated that solubility was the most important determinant of a good insert-specific neutralizing immune response, it became a priority to explore methods for increasing the soluble fraction of VP7 fusion proteins and develop effective methods of harvesting semi-purified soluble VP7 proteins.

\subsection{Effect of chemical treatment and amino acid substitutions on the solubility of VP7 fusion proteins}

An investigation was conducted to determine if the solubility of the VP7-144( $\left.\mathrm{P}_{2}\right)$-FMDVepi and VP7-177( $\left.\mathrm{P}_{1}\right)$-FMDVepi proteins could be improved by detergent or other chemical treatments. Cellular lysates were treated with a range of non-ionic detergents, such as TritonX 100 and Nonidet P40 (Roche). Promising results were obtained by treating the particulate fractions of these two proteins with the amino acid 1-arginine. The particulate fractions of VP7-177 $\left(\mathrm{P}_{1}\right)$ FMDVepi and VP7-144( $\left.\mathrm{P}_{2}\right)$-FMDVepi were collected by high speed centrifugation through a $40 \%$ sucrose cushion and resuspended in either PBS buffer or PBS buffer containing $1 \mathrm{M} 1-$ arginine. 1-Arginine visibly cleared the normally turbid protein suspensions (results not shown). These suspensions were layered onto sucrose gradients and the VP7 protein solubility determined by sucrose sedimentation analysis. The results in Fig. 6 show that in case of both VP7-177( $\left.\mathrm{P}_{1}\right)$-FMDVepi and VP7-144( $\left.\mathrm{P}_{2}\right)$-FMDVepi, approximately $40 \%$ of the proteins were in the soluble fractions of the gradient (fractions 8-10) following resuspension in PBS buffer, with the remainder in the pellet fraction. However, all of the proteins were in the soluble fractions of the gradient following arginine treatment.

Next the effect of 1-Arginine treatment on particulate fractions of VP7 proteins with two different AHSV-4 VP2 peptide inserts was investigated. These constructs included VP7-177( $\left.\mathrm{P}_{1}\right)$-VP2epiB with a 23 amino acid epiB insert (aa 377-400) and VP7-144( $\left.\mathrm{P}_{2}\right)-\mathrm{VP} 2(110 \mathrm{aa})$ with a 110aa (aa 
298-408) peptide insert that overlaps epiB and an upstream epitope epiA located in the region of amino acids 321-339 (Martinez-Torrecuadrada et al., 2001) The constructs were selected because they both appeared to be insoluble. When cellular lysates containing the two proteins were analyzed on sucrose gradients (Fig. 7A), the bulk of the expressed proteins were in the pellet fractions of the gradient. When the pellet fractions of these two proteins were resuspended in PBS with $1 \mathrm{M}$ 1-Arginine and analyzed (Fig. 7B), a significant portion of the particulate fraction of both VP7-144( $\left.\mathrm{P}_{2}\right)-\mathrm{VP} 2(110 \mathrm{aa})$ and VP7-177( $\left.\mathrm{P}_{1}\right)$-VP2epiB proteins were found in the soluble fractions of the gradient. Arginine treatment of the pellet fractions was used for the bulk preparation of soluble fractions of proteins VP7-144( $\left.\mathrm{P}_{2}\right)-\mathrm{VP} 2(110 \mathrm{aa})$ and VP7-177( $\left.\mathrm{P}_{1}\right)-\mathrm{VP} 2$ epiB as indicated in Section 2.

Table 2. Immune response in guinea pigs against soluble and particulate fractions of VP7-177( $\left.\mathrm{P}_{1}\right)$ FMDVepi.

\begin{tabular}{|c|c|c|c|c|c|c|c|}
\hline \multirow[t]{2}{*}{ Antigen } & \multirow[t]{2}{*}{ Adjuvant } & \multicolumn{3}{|c|}{$\begin{array}{l}\text { FMDV ELISA } \\
\text { Titres: } \log _{10} \text { reciprocal }\end{array}$} & \multicolumn{3}{|c|}{$\begin{array}{l}\text { FMDV neutralization } \\
\text { Titres: } \log _{10} \text { reciprocal }\end{array}$} \\
\hline & & $\begin{array}{l}21 \\
\text { days }\end{array}$ & $\begin{array}{l}42 \\
\text { days }\end{array}$ & Average $^{a}$ & $\begin{array}{l}21 \\
\text { days }\end{array}$ & $\begin{array}{l}42 \\
\text { days }\end{array}$ & Average $^{\mathrm{a}}$ \\
\hline \multirow[t]{6}{*}{$\begin{array}{l}\left.\text { VP7-177( } \mathrm{P}_{1}\right) \text {-FMDVepi } \\
\text { soluble }\end{array}$} & $\begin{array}{l}\text { Complete } \\
\text { Freunds }\end{array}$ & 1.9 & 3.5 & $\begin{array}{l}3.7 \\
( \pm 0.45)\end{array}$ & 1.6 & 2.4 & $\begin{array}{l}2.6 \\
( \pm 0.42)\end{array}$ \\
\hline & & 2.2 & 3.2 & & 1.4 & 2.2 & \\
\hline & & 4.1 & 4.1 & & 1.8 & 3.1 & \\
\hline & & 3.8 & 4.1 & & 1.7 & 2.9 & \\
\hline & $\begin{array}{l}\text { Incomplete } \\
\text { Freunds }\end{array}$ & 2.8 & 3.5 & $\begin{array}{l}3.4 \\
( \pm 0.21)\end{array}$ & 1.4 & 2.8 & $\begin{array}{l}2.6 \\
( \pm 0.28)\end{array}$ \\
\hline & & 2.8 & 3.2 & & 1.9 & 2.4 & \\
\hline \multirow[t]{3}{*}{$\begin{array}{l}\text { VP7-177( }\left(\mathrm{P}_{1}\right) \text {-FMDVepi } \\
\text { particulate }\end{array}$} & $\begin{array}{l}\text { Complete } \\
\text { Freunds }\end{array}$ & 1.1 & 1.6 & $2.2( \pm 0.6)$ & 1.2 & 1.2 & $\begin{array}{l}1.5 \\
( \pm 0.28)\end{array}$ \\
\hline & & 1.1 & 2.8 & & 1.2 & 1.8 & \\
\hline & & 1.6 & 2.2 & & 1.2 & 1.5 & \\
\hline \multirow[t]{3}{*}{ VP7-177( $\left.\mathrm{P}_{1}\right)$} & $\begin{array}{l}\text { Complete } \\
\text { Freunds }\end{array}$ & 1.2 & 1.3 & 1.3 & $\mathrm{ND}$ & ND & ND \\
\hline & & 1.3 & 1.3 & & ND & ND & \\
\hline & & 1.3 & 1.3 & & ND & ND & \\
\hline
\end{tabular}

\footnotetext{
${ }^{\mathrm{a}}$ Standard deviation of the averages at 42 days in brackets.
} 


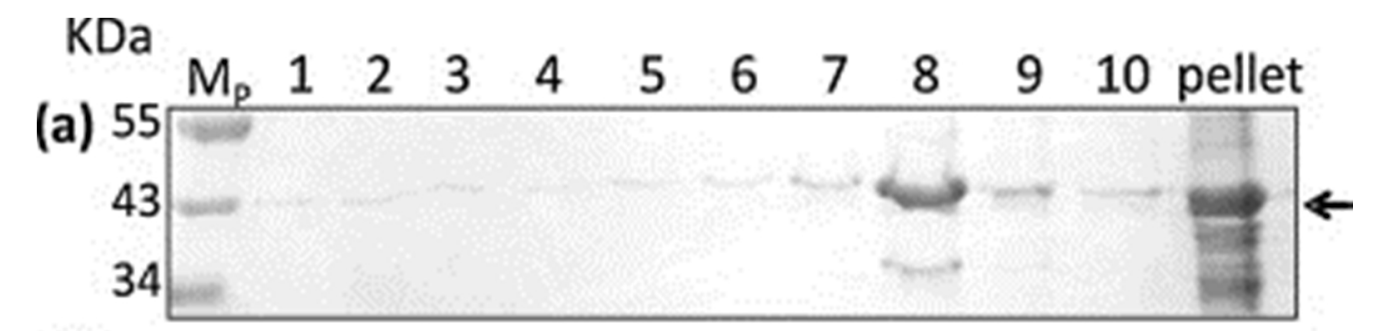

(b) 55

43

34

\section{VP7-144( $\left(P_{2}\right)$-FMDVepi}

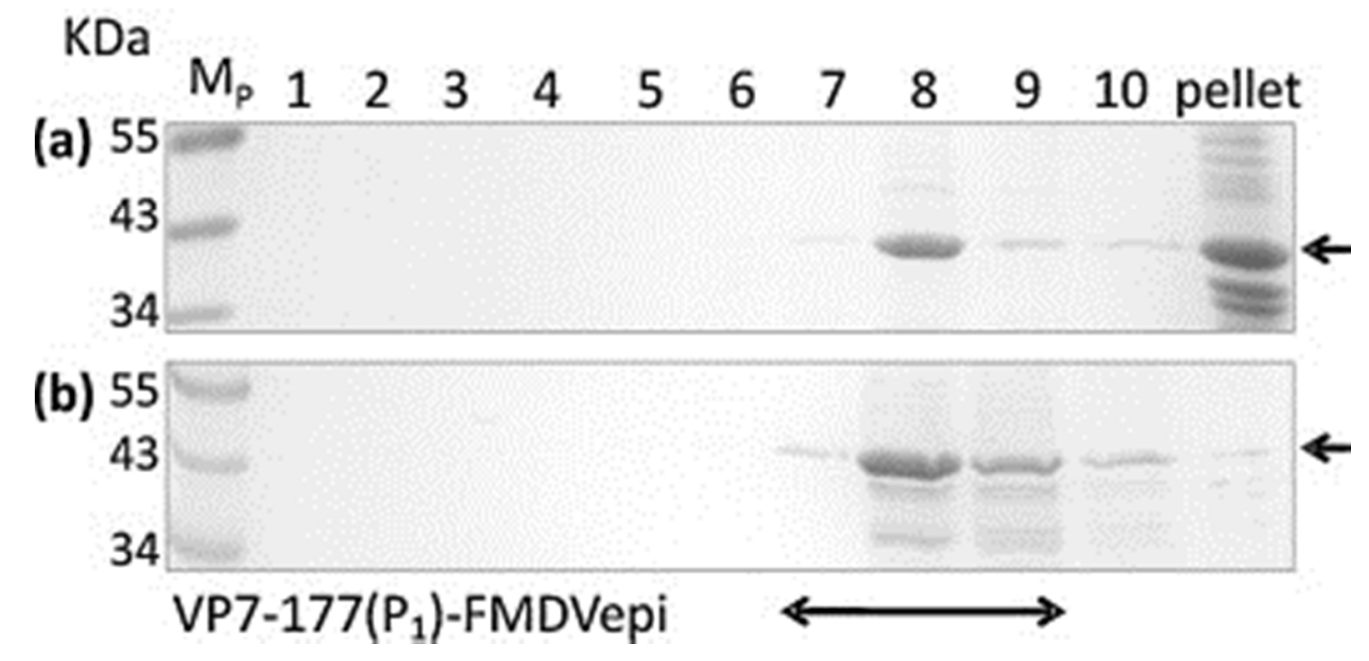

Fig. 6. SDS-PAGE analyses of the fractions obtained following sucrose gradient sedimentation separation of VP7177( $\left.\mathrm{P}_{1}\right)$-FMDVepi and VP7-144( $\left.\mathrm{P}_{2}\right)$-FMDVepi protein aggregates after (a) resuspension in PBS buffer or (b) in PBS buffer with $1 \mathrm{M}$ arginine. Sucrose gradient fractions and pellets were analyzed by SDS-PAGE and the proteins visualised by Coomassie Blue staining. The double sided arrow at the bottom of the gel indicates the soluble fractions of the gradient. $M_{\mathrm{P}}$ is a PageRuler ${ }^{\mathrm{TM}}$ prestained molecular size protein ladder. The arrow on the side of gel indicates the position of a unique protein corresponding to the expected size of the VP7-FMDV fusion protein. 

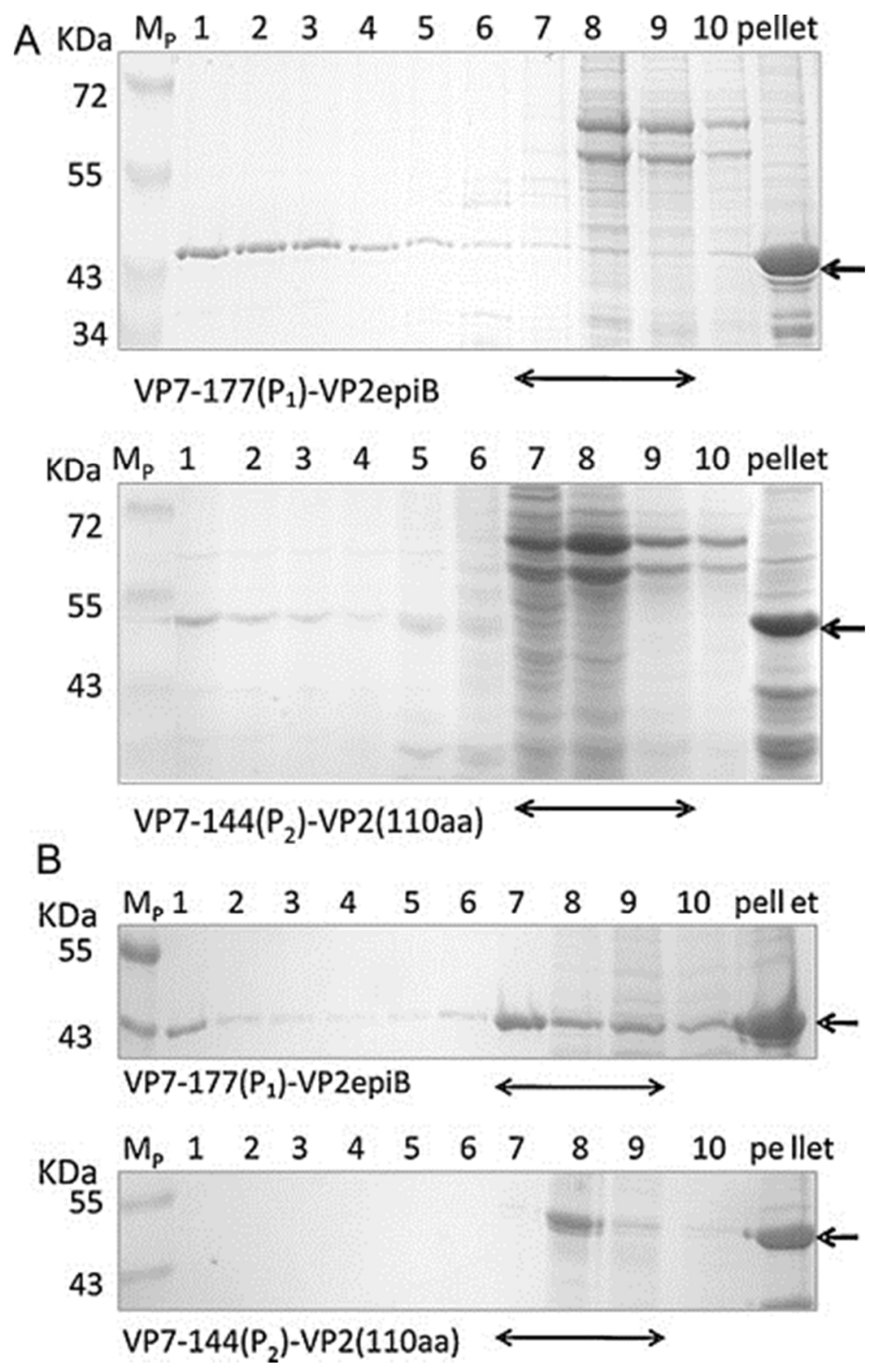

Fig. 7. (A) SDS-PAGE analyses of the fractions obtained following sucrose gradient sedimentation of VP7 fusion proteins, VP7-177( $\left.\mathrm{P}_{1}\right)$-VP2epiB and VP7-144( $\left.\mathrm{P}_{2}\right)$-VP2(110aa), as described in the legend of Fig. 2. Sucrose gradient fractions, and pellets, were analyzed via SDS-PAGE and the proteins visualised by Coomassie Blue staining. The double sided arrow at the bottom of the gel indicates the soluble fractions of the gradient. $M_{\mathrm{P}}$ is a PageRuler ${ }^{\mathrm{TM}}$ prestained molecular size protein ladder. The arrow on the side of gel indicates the position of a unique protein, corresponding to the expected size of the VP7-VP2 fusion protein. (B) SDS-PAGE analyses of proteins solubilized by arginine treatment of the particulate fractions of VP7-177( $\left.\mathrm{P}_{1}\right)-\mathrm{VP} 2 \mathrm{epiB}$ and VP7-144( $\left.\mathrm{P}_{2}\right)-\mathrm{VP} 2(110 \mathrm{aa})$ proteins respectively. Proteins in the particulate fractions were resuspended in PBS buffer with $1 \mathrm{M}$ l-arginine and analyzed by centrifugation and electrophoresis, as described in the legend of Fig. 2 . The proteins were visualised by Coomassie Blue staining. $M_{\mathrm{P}}$ is a PageRuler ${ }^{\mathrm{TM}}$ prestained molecular size protein ladder.

In order to explore some alternative methods of increasing VP7 solubility, we also investigated whether a single amino acid substitution in position 345 of WT VP7 from an uncharged leucine residue to a positively charged arginine residue could enhance VP7 solubility. The equivalent 
leucine residue in position 351 in the VP7-177 $\left(\mathrm{P}_{1}\right)$ vector protein was similarly substituted by arginine. The mutated VP7-L345R and VP7-177( $\left.\mathrm{P}_{1}\right)$-L351R proteins were expressed in insect cells and analyzed by sucrose density analysis to detect any changes in VP7 solubility. The position of the mutant VP7 proteins on SDS-PAGE gels was confirmed by immunoblot analysis with VP7 antibodies (Fig. 8). The L345R substitution in the C-terminal of the native AHSV-9 VP7 protein resulted in a significant increase in the solubility of the WT VP7 protein from less than $10 \%$ (Fig. 2) to $48 \%$. The same amino acid substitution in position 351 increased the solubility of the VP7-177( $\left.\mathrm{P}_{1}\right)$ vector protein from just less than $30 \%$ (Fig. 2 ) to more than $40 \%$. In addition to the Leu-Arg substitution, the cloning strategy also resulted in a valine to alanine substitution in positions 344 and 350 of proteins WT VP7 and VP7-177( $\left.\mathrm{P}_{1}\right)$, respectively. These non-polar substitutions are unlikely to have had an impact on the solubility of the mutant proteins.
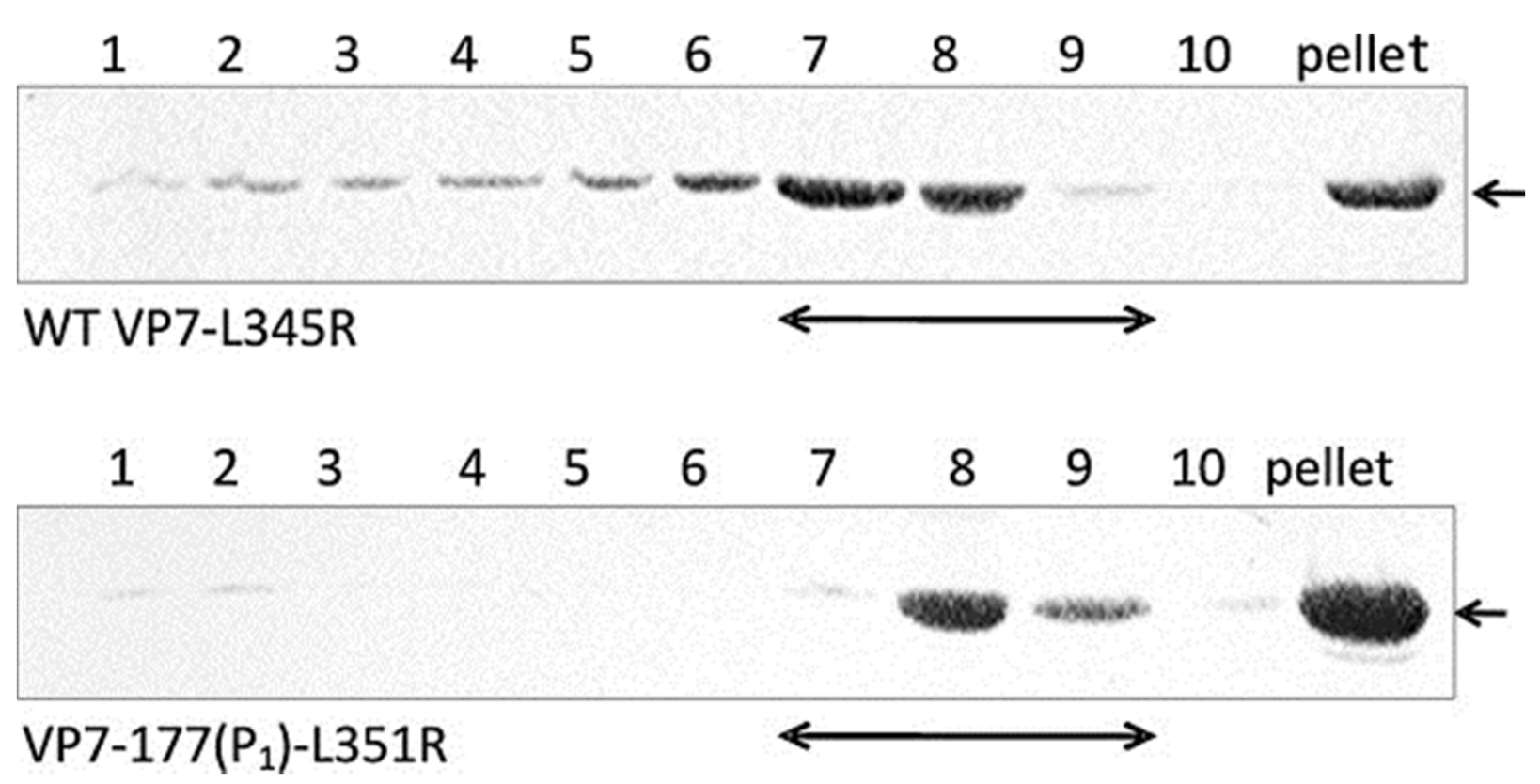

Fig. 8. Immunoblot analyses, using guinea pig anti-VP7 antibodies, of the sucrose fractions and pellet obtained following sucrose gradient sedimentation of cellular lysates containing proteins WT VP7-L345R and VP7-177( $\left.\mathrm{P}_{1}\right)$ L351R, as described in Fig. 2. The double sided arrow at the bottom of the gel indicates the soluble fractions of the gradient. The arrow on the side of gel indicates the position of the VP7 protein.

\subsection{Immune response against arginine solubilized VP7 fusion proteins}

Although the particulate fraction of VP7-177( $\left.\mathrm{P}_{1}\right)$-FMDVepi is fully solubilized by l-arginine treatment (Fig. 6), it was not known how this treatment would affect the immune response elicited against this protein. It was also necessary to explore the effect of antigen dose and adjuvant on the immune response. Animals were inoculated with either $20 \mu \mathrm{g}$ or $80 \mu \mathrm{g}$ of arginine solubilized VP7-177( $\left.\mathrm{P}_{1}\right)$-FMDVepi in the presence of either complete Freunds adjuvant, a combination of $\mathrm{AlOH}$ and Saponin adjuvant or Montanide ISA 206B adjuvant. All animals 
Table 3. Immune response in guinea pigs against arginine or sarkosyl solubilized VP7-177( $\left.\mathrm{P}_{1}\right)$ FMDVepi antigen in the presence of different adjuvants.

\begin{tabular}{|c|c|c|c|c|}
\hline \multirow[t]{2}{*}{ Antigen } & \multirow[t]{2}{*}{$\begin{array}{l}\text { Dose: primary } \\
\text { and boost }\end{array}$} & \multirow[t]{2}{*}{$\begin{array}{l}\text { Adjuvant: primary } \\
\text { and boost }\end{array}$} & \multicolumn{2}{|c|}{$\begin{array}{l}\text { FMDV } \\
\text { neutralization } \\
\text { Titres: } \log _{10} \\
\text { reciprocal }\end{array}$} \\
\hline & & & $\begin{array}{l}42 \\
\text { days }\end{array}$ & Average $^{a}$ \\
\hline \multirow{25}{*}{$\begin{array}{l}\left.\text { VP7-177( } \mathrm{P}_{1}\right) \text {-FMDVepi } \\
\text { arginine solubilized }\end{array}$} & $20 \mu \mathrm{g}$ & Complete Freunds & 3.2 & $3.0( \pm 0.11)$ \\
\hline & & & 3.4 & \\
\hline & & & 3.0 & \\
\hline & & & 2.9 & \\
\hline & & & 2.7 & \\
\hline & $20 \mu \mathrm{g}$ & $\begin{array}{l}\text { Combination } \mathrm{AlOH} \text { and } \\
\text { Saponin }\end{array}$ & 1.3 & $1.6( \pm 0.53)$ \\
\hline & & & 1.6 & \\
\hline & & & 1.1 & \\
\hline & & & 2.3 & \\
\hline & $50 \mu \mathrm{g}$ & $\begin{array}{l}\text { Combination } \mathrm{AlOH} \text { and } \\
\text { Saponin }\end{array}$ & 2.4 & $2.2( \pm 0.29)$ \\
\hline & & & 1.8 & \\
\hline & & & 2.4 & \\
\hline & & & 2.1 & \\
\hline & $80 \mu \mathrm{g}$ & $\begin{array}{l}\text { Combination } \mathrm{AlOH} \text { and } \\
\text { Saponin }\end{array}$ & 2.4 & $2.4( \pm 0.35)$ \\
\hline & & & 2.8 & \\
\hline & & & 2.0 & \\
\hline & & & 2.4 & \\
\hline & $20 \mu \mathrm{g}$ & Montanide ISA 206B & 3.0 & $2.9( \pm 0.39)$ \\
\hline & & & 2.3 & \\
\hline & & & 3.1 & \\
\hline & & & 3.1 & \\
\hline & $80 \mu \mathrm{g}$ & Montanide ISA 206B & 3.0 & $3.0( \pm 0.31)$ \\
\hline & & & 2.5 & \\
\hline & & & 3.1 & \\
\hline & & & 3.2 & \\
\hline \multirow[t]{5}{*}{$\begin{array}{l}\left.\text { VP7-177( } \mathrm{P}_{1}\right) \text {-FMDVepi } \\
\text { sarkosyl solubilized }\end{array}$} & $20 \mu \mathrm{g}$ & Complete Freunds & 2.9 & $3.0( \pm 0.27)$ \\
\hline & & & 3.1 & \\
\hline & & & 3.0 & \\
\hline & & & 3.2 & \\
\hline & & & 2.9 & \\
\hline
\end{tabular}

\footnotetext{
${ }^{\mathrm{a}}$ Standard deviation of average in brackets.
} 
received a boost 3 weeks later with the same antigen dose and adjuvant. The FMDV serum neutralization titres and FMDV specific ELISA titres were determined 3 weeks later on day 42 of the animal trial. The effect of arginine solubilization was also compared to that of VP7$177\left(\mathrm{P}_{1}\right)$-FMDVepi that was solubilized by sarkosyl treatment. Sarkosyl is a mildly denaturing ionic detergent that does not affect the ability of AHSV VP7 to form trimers but effectively solubilizes aggregated VP7 fusion proteins (results not shown). Sarkosyl was removed by dialysis prior to use in the trial. The results of the neutralization titres are shown in Table 3 . In all cases the neutralization titres reflected the ELISA titres obtained (not shown).

Table 4. Insert-specific ELISA and AHSV-4 neutralization antibody titres after innoculation of guinea pigs with arginine solubilized VP7-177( $\left.\mathrm{P}_{1}\right)$-VP2epiB and VP7-144( $\left.\mathrm{P}_{2}\right)$-VP2(110aa).

\begin{tabular}{|c|c|c|c|c|}
\hline \multirow[t]{2}{*}{ Arginine solubilized antigen $(40 \mu \mathrm{g})$} & \multicolumn{2}{|c|}{$\begin{array}{l}\text { FMDV ELISA } \\
\text { Titres: } \log _{10} \text { reciprocal }\end{array}$} & \multicolumn{2}{|c|}{$\begin{array}{l}\text { FMDV neutralization } \\
\text { Titres: } \log _{10} \text { reciprocal }\end{array}$} \\
\hline & 42 days & Average $^{a}$ & 42 days & Average $^{a}$ \\
\hline \multirow[t]{5}{*}{ VP7-177( $\left.\mathrm{P}_{1}\right)-$ VP2epiB } & 4.51 & $4.14( \pm 0.50)$ & 1.20 & $1.08( \pm 0.16)$ \\
\hline & 4.51 & & 0.90 & \\
\hline & 4.20 & & 1.20 & \\
\hline & 3.30 & & 0.90 & \\
\hline & 4.20 & & 1.20 & \\
\hline \multirow[t]{5}{*}{ VP7-144(P 2$)-V P 2(110 a a)$} & 4.20 & $3.66( \pm 0.49)$ & 1.20 & $0.96( \pm 0.25)$ \\
\hline & 3.30 & & 0.90 & \\
\hline & 4.20 & & 1.20 & \\
\hline & 3.30 & & 0.60 & \\
\hline & 3.30 & & 0.90 & \\
\hline
\end{tabular}

${ }^{\mathrm{a}}$ Standard deviation of the average titres at 42 days in brackets.

The average FMDV-specific neutralization titres against the arginine and sarkosyl-solubilized VP7-177 $\left(\mathrm{P}_{1}\right)$-FMDVepi were near identical, indicating that a mild, non-denaturing solubilizing agent such as arginine is as effective as sarkosyl detergent for completely solubilizing the antigen. The FMDV neutralizing antibody response against $20 \mu \mathrm{g}$ of arginine solubilized VP7177( $\left(\mathrm{P}_{1}\right)$-FMDVepi in the presence of Montanide ISA 206B adjuvant is significantly better than the response elicited in the presence of a combination of $\mathrm{AlOH}$ and Saponin. The immune response against soluble VP7-177( $\left.\mathrm{P}_{1}\right)$-FMDVepi in the presence of the AlOH and Saponin combination adjuvant improves with an increase in the antigen dose to $80 \mu \mathrm{g}$ but it is still below that of the response against $20 \mu \mathrm{g}$ antigen in the presence of Montanide ISA 206B adjuvant. However, the average neutralization titres with the smaller antigen dose was higher in the presence of arginine and the standard deviation from the average smaller, indicating better reproducibility and consistency in the response. This consistency is also reflected by the results with sarkosyl solubilized VP7-177( $\left.\mathrm{P}_{1}\right)$-FMDVepi, suggesting that there is a big advantage in presenting soluble antigens to the immune system in the presence of reagents that prevent or reverse protein aggregation.

We also investigated the immune response against a $40 \mu \mathrm{g}$ dose of VP7-144( $\left.\mathrm{P}_{2}\right)-\mathrm{VP} 2(110 \mathrm{aa})$ and VP-177( $\left.\mathrm{P}_{1}\right)$-VP2epiB proteins, solubilized by $1 \mathrm{M}$ 1-arginine. The results are shown in Table 4. 
Both fusions indicated an excellent AHSV VP2 insert-specific antibody response when measured by a VP2 epiB specific ELISA, with $\log _{10}$ reciprocal ELISA titres as high as 4 . We also

compared the virus neutralization titres but although some of the mice sera showed some level of type-specific neutralization over and above the background titre of between 0.6 and 0.9 , the titres were generally too low and variable to make a significant conclusion.

\section{Discussion}

A common strategy for enhancing the immunogenicity of small peptides is to display them on multimeric protein substructures, such as virus-like or core-like particles (Kaumaya et al., 1992). This strategy has been investigated for a large number of different viral proteins ([Kaba et al., 2003], [Lin et al., 1996], [Pumpens et al., 1995] and [Roy, 1996b]). In the case of AHSV VP7, we have explored an alternative strategy by presenting foreign peptides on the surface of soluble AHSV VP7 trimers. This display strategy is based on the assumption that the physical constraints associated with VP7 trimer formation will provide some of the structural rigidity required to ensure a reproducible insert-specific immune response. It is also postulated that the humoral immune response against the number of free, individual VP7 trimers normally associated with one CLP, may have some advantage over the response against a single CLP particle. An additional advantage may be that the chimeric VP7 trimers, incapable of forming stable CLPs (Limn et al., 2000) may also be used for immune display. The success of such a display strategy is, however, dependent on a number of criteria, the most important of which are the solubility of the VP7 fusion proteins and the ability to form stable trimers.

We have shown that the solubility of AHSV VP7 is affected by the insertion of amino acids into targeted sites within the AHSV VP7 top domain. The insertion of the 6-mer peptide $\mathrm{P}_{2}$ downstream of VP7 amino acid position 144, converted VP7 into an almost completely soluble protein whereas the insertion of $\mathrm{P}_{1}$ downstream of amino acid 177 also increased the solubility of the mutated VP7 to close to $30 \%$. The effect of these insertions is both site and peptide specific as the insertion of $\mathrm{P}_{1}$ downstream of amino acid position 200 had no marked effect on protein solubility and $\mathrm{P}_{1}$ and $\mathrm{P}_{2}$ had a different effect on solubility when inserted downstream of amino acid 144. The solubility of AHSV VP7 is, however, not only affected by modifications to the top domain. We have also shown that a single, targeted L345R amino acid substitution in the Cterminal of both WT AHSV VP7 and vector protein VP7-177( $\left.\mathrm{P}_{1}\right)$, resulted in a large increase in the solubility of these proteins. These results confirm the prediction that the leucine-345 in the ninth C-terminal helix of the bottom domain contributes to AHSV VP7 insolubility (Monastyrskaya et al., 1997).

It was also important to assess the effect of these modifications on the ability of AHSV VP7 to form trimers. The detection of AHSV VP7 trimers by SDS-PAGE indicated that when the protein samples were not heat denatured prior to electrophoresis, WT AHSV VP7 did not migrate as a $39 \mathrm{kDa}$ monomer but as larger multimer. A multimer of exactly the same size was also observed in VP7-177( $\left.\mathrm{P}_{1}\right)$ whereas in VP7-144( $\left.\mathrm{P}_{1}\right)$ and VP7-144 $\left(\mathrm{P}_{2}\right)$ both the multimer and the monomer were observed. In the case of VP7-200( $\left.\mathrm{P}_{1}\right)$ we never observed the multimer suggesting that it was unstable in the presence of SDS. Since the size of the multimer was larger than the expected $120 \mathrm{kDa}$, we also used sedimentation analysis to assess trimer formation similar to what has been used to assess the size of BTV VP7 trimers (Limn et al., 2000). Using 
this strategy, we compared the sedimentation profile of VP7 in the soluble fraction of the AHSV vector proteins to that of BTV VP7 and estimated the size of the VP7 multimers through cosedimentation with a number of selected sedimentation size markers. These results confirmed that all the vectors proteins, including VP7-200( $\left.\mathrm{P}_{1}\right)$, sedimented exactly as would be expected from $120 \mathrm{kDa}$ VP7 trimers with a sedimentation profile indistinguishable from that of BTV VP7.

The variables affecting the solubility, particle formation and trimer formation of chimeric AHSV VP7 proteins most likely include modifications that influence the hydrophilicity of the VP7 top domain. In this respect the hydrophilicity of the inserted peptide may be important but equally important is whether the inserted amino acids can be optimally presented to the aqueous environment. This will depend on correct folding of the peptide and also on VP7 trimer space constraints largely determined by the site of insertion in the VP7 top domain. In the AHSV trimer (Fig. 1) there are distinct differences in the proximity of the insertion sites. The three 144 amino acids as well as the three 177 amino acids are situated far apart in the trimer and the peptides inserted into these sites are therefore less likely to suffer from space constraints. The 200 amino acid insertion sites on the other hand are in close proximity and this site is the most likely to present space constraints. Our results appear to confirm some of these predictions. The 144 and 177 insertion sites were the only sites where the insertion of a peptide resulted in an increase in VP7 solubility. The insertion of the $\mathrm{P}_{1}$ peptide downstream of amino acid 200 did not increase solubility and affected the stability of the VP7-200( $\left.\mathrm{P}_{1}\right)$ multimer. It is more difficult to predict the effect of inserting larger peptides into the different sites because it is not known how these peptides are normally folded and what space constraints are involved.

The insertion of the FMDV VP1 peptide (aa 129-164) into the VP7-177( $\left.\mathrm{P}_{1}\right)$ vector increased the vector solubility to approximately $40 \%$ and it did not affect the ability of the VP7-177( $\left.\mathrm{P}_{1}\right)$ FMDVepi protein to form trimers. The FMDV peptide is a largely hydrophilic peptide that overlaps a cluster of B-cell neutralizing epitopes ([Basak et al., 1996], [Zamorano et al., 1994] and [Zamorano et al., 1998]). It forms a natural loop on the VP1 protein of FMDV (Aggarwal and Barnett, 2002) and the fusion of this loop with the flexible amino acid loop 175-180 of the VP7 top domain (Basak et al., 1996) appears to result in a significant increase in hydrophilicity of the VP7 top domain. However, the insertion resulted in a distortion of the particles associated with the particulate fraction of VP7-177( $\left.\mathrm{P}_{1}\right)$-FMDVepi. This is not surprising, considering that these hydrophilic inserts in top domain may well distort the way the double layer of VP7 trimers interact with one another. No such distorting effect was observed when peptide $\mathrm{P}_{1}$ was inserted after VP7 amino acid position 177 and the VP7-177( $\left.\mathrm{P}_{1}\right)$ particles were indistinguishable from those described for WT VP7 ([Burrage and Laegreid, 1994] and [Chuma et al., 1992]).

The most important question addressed was, however, how well the soluble VP7-177( $\left.\mathrm{P}_{1}\right)$ FMDVepi trimers present the FMDV peptide insert to the immune system. The FMDV VP1 peptide insert in VP7-177( $\left.\mathrm{P}_{1}\right)$ FMDVepi is well known for its ability to induce a significant humoral immune response (Zamorano et al., 1994). Wild-type VP7 particles have previously been explored for the induction of a protective immune response (Wade-Evans et al., 1997) but there are no reports on the use of soluble AHSV trimers in eliciting such a response. We observed a large difference in the insert-specific immune response against the particulate and soluble fractions of VP7-177( $\left.\mathrm{P}_{1}\right)$-FMDVepi. The FMDV insert-specific ELISA and FMDV neutralization antibody titres elicited against the soluble fraction were as much as ten times 
higher than the titres elicited against the particulate fraction. The strong insert-specific response against the soluble fraction of VP7-177( $\left.\mathrm{P}_{1}\right)$-FMDVepi was confirmed when the experiment was repeated by using VP7-177( $\left.\mathrm{P}_{1}\right)$-FMDVepi solubilized by either l-arginine or sarkosyl. The prevention of protein aggregation by the amino acid l-arginine or the detergent sarkosyl resulted in an enhanced immune response. Sarkosyl is an ionic detergent. At a high concentration it denatures proteins but at a lower concentration it is used in the purification of certain viruses such as FMDV to remove cellular debris without loss in virus infectivity. Sarkosyl does not affect AHSV VP7 trimer stability as has been demonstrated by the fact that it does not affect the sedimentation profile of the trimers. We nevertheless removed the sarkosyl from the VP7 solution prior to the use of the antigen in the assessment of the immune response in the animal studies.

Freunds adjuvant did not significantly enhance the immune response in comparison to incomplete Freunds. We also compared the immune response elicited against a $20 \mu \mathrm{g}$ and $80 \mu \mathrm{g}$ dose of VP7-177( $\left.\mathrm{P}_{1}\right)$-FMDVepi in the presence of a AlOH and Saponin combination adjuvant and a Montanide ISA 206B adjuvant. The Montanide ISA 206 adjuvant that is frequently used together with FMDV vaccines was significantly better at enhancing the immune response at a dose of $20 \mu \mathrm{g}$ than the $\mathrm{AlOH}$ and Saponin adjuvant combination. The strategy of reversing the protein-protein aggregation of VP7 fusion proteins by the addition of 1-arginine was also used to fully solubilize VP7-144( $\left.\mathrm{P}_{2}\right)$-FMDVepi from the particulate fraction. 1-Arginine does not denature the proteins but appears to add a negative charge which prevents or reverses proteinprotein aggregation (Tsumoto et al., 2005). The effect of l-Arginine on proteins is relatively mild. It may lower the melting temperatures of certain proteins but it is not a denaturing agent (Ishibashi et al., 2005). This method was also used to partially solubilize VP7 with different AHSV-VP2 peptide inserts enabling us to isolate soluble protein fractions of VP7-177( $\left.\mathrm{P}_{1}\right)$ VP2epiB and VP7-144( $\left.\mathrm{P}_{2}\right)-\mathrm{VP} 2(110 \mathrm{aa})$. We obtained a good insert-specific antibody response against these AHSV VP2 peptides as measured by means of an epiB specific ELISA test. The AHSV-4 neutralization titres elicited against both these constructs were low but in a number of animals consistently above that of the pre-bleed control sera.

The neutralization-specific, outer capsid protein VP2 has been the target of most recombinant vaccine strategies against AHSV ([Guthrie et al., 2009] and [Roy, 1996b]). However, the insolubility of the VP2 proteins that are expressed in insect cells remains the main stumbling block (Scanlen et al., 2002). The possibility of using smaller epitope domains of AHSV VP2, instead of the full-length VP2, has been explored and a number of neutralization-specific domains were identified between VP2 amino acid residues 253 and 413 ([MartinezTorrecuadrada and Casal, 1995], [Martinez-Torrecuadrada et al., 2001] and [Venter et al., 2000]). However, expression of these peptides in bacterial or insect cells renders them largely insoluble and non-immunogenic (Venter et al., 2000). Chimeric VP7 trimers allow for the presentation of VP2 peptides to the immune system in a soluble form.

The AHSV VP7 display strategy has a number of advantages. The VP7 fusion proteins are expressed in a good yield with a recovery of soluble VP7-177( $\left.\mathrm{P}_{1}\right)$-FMDVepi of at least $6.5 \mathrm{mg} / 10^{8} \mathrm{Sf} 9$ cells. It is possible to use cellular lysates that contain the VP7 fusion proteins without further purification as an antigen solution after arginine treatment. However, a much purer antigen is obtained if the aggregated VP7 fusion proteins are collected by relatively low 
speed centrifugation followed by treatment of the particulate fraction with arginine to solubilize the VP7 fusion proteins. The soluble proteins may be freeze-dried in the presence of arginine and remain fully soluble after reconstitution in water. The presence of arginine has been shown to enhance the immune response and there is no need to remove it from the immunogen solution. The 3 log FMDV neutralization titres we observed with construct VP7-177(P1)-FMDVepi in guinea pigs is much higher than the $2 \log$ neutralization titres that are normally considered sufficient to protect cattle against FMDV infection but we cannot extrapolate the guinea pig results to larger animals and these experiments are in the pipe-line. The AHSV VP7 display has a significant advantage in that the modifications of the VP7 top domain in many cases increase VP7 solubility without affecting trimer formation. We have inserted large proteins such as eGFP downstream of sites 144 and 177 . These insertions generated a large fraction of soluble fluorescing proteins with a sedimentation profile corresponding to VP7-eGFP trimers (unpublished results).

\section{Acknowledgements}

The work was largely supported by BioPad Bric grant BP050 with additional support from the National Research Foundation. The technical support from Flip Wege is greatly appreciated as well the support form Jan Esterhuyzen from the OVI for the analysis of the immune sera. We also acknowledge the support from Joanne Riley who constructed vector VP7-144( $\left.\mathrm{P}_{2}\right)$ as part of her MSc dissertation and Nicolas Smalle who constructed VP7-177( $\left.\mathrm{P}_{1}\right)$-VP2epiB as part of an honours project. The contribution of Karen Lacheiner and Dr Vida van Staden to the project and the completion of the paper is gratefully acknowledged.

\section{References}

Adler, S., Reay, P., Roy, P. and Klenk, H.D. 1998. Induction of T cell response by bluetongue virus core-like particles expressing a T cell epitope of the M1 protein of influenza A virus, Med. Microbiol. Immunol. (Berl.) 187 (2), pp. 91-96.

Aggarwal, N. and Barnett, P.V. 2002. Antigenic sites of foot-and-mouth disease virus (FMDV): an analysis of the specificities of anti-FMDV antibodies after vaccination of naturally susceptible host species, J. Gen. Virol. 83 (Pt 4), pp. 775-782.

Basak, A.K., Gouet, P., Grimes, J., Roy, P. and Stuart, D. 1996. Crystal structure of the top domain of African horse sickness virus VP7: comparisons with bluetongue virus VP7, J. Virol. 70 (6), pp. 3797-3806.

Burrage, T.G. and Laegreid, W.W. 1994. African horsesickness: pathogenesis and immunity, Comp. Immunol. Microbiol. Infect. Dis. 17 (3-4), pp. 275-285.

Burroughs, J.N., O’Hara, R.S., Smale, C.J., Hamblin, C., Walton, A., Armstrong, R. and Mertens, P.P. 1994. Purification and properties of virus particles, infectious subviral particles, cores and VP7 crystals of African horsesickness virus serotype 9, J. Gen. Virol. 75 (Pt 8), pp. $1849-1857$. 
Chuma, T., Le Blois, H., Sanchez-Vizcaino, J.M., Diaz-Laviada, M. and Roy, P. 1992. Expression of the major core antigen VP7 of African horsesickness virus by a recombinant baculovirus and its use as a group-specific diagnostic reagent, J. Gen. Virol. $73(\mathrm{Pt} 4)$, pp. 925931.

Ghosh, M.K., Borca, M.V. and Roy, P. 2002. Virus-derived tubular structure displaying foreign sequences on the surface elicit CD4+ Th cell and protective humoral responses, Virology 302 (2) pp. 383-392.

Grimes, J., Basak, A.K., Roy, P. and Stuart, D. 1995. The crystal structure of bluetongue virus VP7, Nature 373 (6510), pp. 167-170.

Guthrie, A.J., Quan, M., Lourens, C.W., Audonnet, J.C., Minke, J.M., Yao, J., He, L., Nordgren, R., Gardner, I.A. and Maclachlan, N.J. 2009. Protective immunization of horses with a recombinant canarypox virus vectored vaccine co-expressing genes encoding the outer capsid proteins of African horse sickness virus, Vaccine 27 (33), pp. 4434-4438.

Ishibashi, M., Tsumoto, K., Tokunaga, M., Ejima, D., Kita, Y. and Arakawa, T. 2005. Is arginine a protein-denaturant?, Protein Expr. Purif. 42 (1), pp. 1-6.

Kaba, S.A., Hemmes, J.C., Van Lent, J.W., Vlak, J.M., Nene, V., Musoke, A.J. and Van Oers, M.M. 2003. Baculovirus surface display of Theileria parva p67 antigen preserves the conformation of sporozoite-neutralizing epitopes, Protein Eng. 16 (1), pp. 73-78.

Kaumaya, P.T., VanBuskirk, A.M., Goldberg, E. and Pierce, S.K. 1992. Design and immunological properties of topographic immunogenic determinants of a protein antigen (LDHC4) as vaccines, J. Biol. Chem. 267 (9), pp. 6338-6346.

Larke, N., Murphy, A., Wirblich, C., Teoh, D., Estcourt, M.J., McMichael, A.J., Roy, P. and Hanke, T. 2005. Induction of human immunodeficiency virus type 1-specific T cells by a bluetongue virus tubule-vectored vaccine prime-recombinant modified virus Ankara boost regimen, J. Virol. 79 (23), pp. 14822-14833.

Le Blois, H. and Roy, P. 1993. A single point mutation in the VP7 major core protein of bluetongue virus prevents the formation of core-like particles, J. Virol. 67 (1), pp. 353-359.

Limn, C.K., Staeuber, N., Monastyrskaya, K., Gouet, P. and Roy, P. 2000. Functional dissection of the major structural protein of bluetongue virus: identification of key residues within VP7 essential for capsid assembly, J. Virol. 74 (18), pp. 8658-8669

Lin, T., Porta, C., Lomonossoff, G. and Johnson, J.E. 1996. Structure-based design of peptide presentation on a viral surface: the crystal structure of a plant/animal virus chimera at $2.8 \mathrm{~A}$ resolution, Fold. Des. 1 (3), pp. 179-187. 
Luckow, V.A., Lee, S.C., Barry, G.F. and Olins, P.O. 1993. Efficient generation of infectious recombinant baculoviruses by site-specific transposon-mediated insertion of foreign genes into a baculovirus genome propagated in Escherichia coli, J. Virol. 67 (8), pp. 4566-4579.

Maree, S. Durbach, S. and Huismans, H. 1998. Intracellular production of African horsesickness virus core-like particles by expression of the two major core proteins, VP3 and VP7, in insect cells, J. Gen. Virol. 79 (Pt 2), pp. 333-337.

Martinez-Torrecuadrada, J.L. and Casal, J.I. 1995. Identification of a linear neutralization domain in the protein VP2 of African horse sickness virus, Virology 210 (2), pp. 391-399.

Martinez-Torrecuadrada, J.L., Langeveld, J.P., Meloen, R.H. and Casal, J.I. 2001. Definition of neutralizing sites on African horse sickness virus serotype $4 \mathrm{VP} 2$ at the level of peptides, J. Gen. Virol. 82 (Pt 10), pp. 2415-2424.

Monastyrskaya, K., Staeuber, N., Sutton, G. and Roy, P. 1997. Effects of domain-switching and site-directed mutagenesis on the properties and functions of the VP7 proteins of two orbiviruses, Virology 237 (2), pp. 217-227.

Pumpens, P., Borisova, G.P., Crowther, R.A. and Grens, E. 1995. Hepatitis B virus core particles as epitope carriers, Intervirology 38 (1-2), pp. 63-74.

Roy, P. 1996a. Genetically engineered particulate virus-like structures and their use as vaccine delivery systems, Intervirology 39 (1-2), pp. 62-71.

Roy, P. 1996b. Orbivirus structure and assembly, Virology 216 (1), pp. 1-11.

Rweyemamu, M.M., Booth, J.C., Head, M. and Pay, T.W. 1978. Microneutralization tests for serological typing and subtyping of foot-and-mouth disease virus strains, J. Hyg. (Lond.) 81 (1), pp. 107-123.

Scanlen, M., Paweska, J.T., Verschoor, J.A. and Van Dijk, A.A. 2002. The protective efficacy of a recombinant VP2-based African horsesickness subunit vaccine candidate is determined by adjuvant, Vaccine 20 (7-8), pp. 1079-1088.

Tanaka, S., Mikhailov, M. and Roy, P. 1995. Synthesis of bluetongue virus chimeric VP3 molecules and their interactions with VP7 protein to assemble into virus core-like particles, Virology 214 (2), pp. 593-601.

Tsumoto, K., Ejima, D., Kita, Y. and Arakawa, T. 2005. Review: Why is arginine effective in suppressing aggregation?, Protein Pept. Lett. 12 (7), pp. 613-619. 
Van Rensburg, H., Haydon, D., Joubert, F., Bastos, A., Heath, L. and Nel, L. 2002. Genetic heterogeneity in the foot-and-mouth disease virus Leader and 3C proteinases, Gene 289 (1-2), pp. 19-29.

Venter, M., Napier, G. and Huismans, H. 2000. Cloning, sequencing and expression of the gene that encodes the major neutralisation-specific antigen of African horsesickness virus serotype 9, J. Virol. Methods 86 (1), pp. 41-53

Wade-Evans et al., 1997 A.M Wade-Evans, L. Pullen, C. Hamblin, R. O’Hara, J.N. Burroughs and P.P. Mertens, African horsesickness virus VP7 sub-unit vaccine protects mice against a lethal, heterologous serotype challenge, J. Gen. Virol. 78 (Pt 7) (1997), pp. 1611-1616.

Zamorano, P.I., Wigdorovitz, A., Chaher, M.T., Fernandez, F.M. Carrillo, C. Marcovecchio, F.E., Sadir, A.M. and Borca, M.V. 1994. Recognition of B and T cell epitopes by cattle immunized with a synthetic peptide containing the major immunogenic site of VP1 FMDV 01 Campos, Virology 201 (2) (1994), pp. 383-387.

Zamorano, P.I., Wigdorovitz, A, Perez Filgueira, D.M., Escribano, J.M. Sadir, A.M. and Borca, M.V. 1998. Induction of anti foot and mouth disease virus $\mathrm{T}$ and $\mathrm{B}$ cell responses in cattle immunized with a peptide representing ten amino acids of VP1, Vaccine 16 (6) (1998), pp. 558563. 